\title{
Evolution Characteristics for Water Eco-Environment of Baiyangdian Lake with 3S Technologies in the Past 60 Years
}

\author{
Yunkai $\mathrm{Li}^{1,2, *, * *}$, Lingyan Wang ${ }^{1, *}$, Hua Zheng ${ }^{2, *}$, Hai Jin ${ }^{3, *}$, Tingwu Xu ${ }^{4, *}$, \\ Peiling Yang ${ }^{1}$, Xiaokai Tijiang ${ }^{1}$, Zengcai Yan ${ }^{5}$, Zhiheng $\mathrm{Ji}^{6}$, Jianli $\mathrm{Lu}^{7}$, \\ Zhanfeng Wang ${ }^{6}$, and Zhiyun Ouyang ${ }^{2 * * *}$ \\ ${ }^{1}$ College of Water Conservancy and Civil Engineering, China Agricultural University, \\ Beijing 100083, P.R. China \\ ${ }^{2}$ State Key Laboratory of Urban and Regional Ecology, Research Centre for Eco-Environmental \\ Sciences, Chinese Academy of Sciences, Beijing 100085, P.R. China \\ ${ }^{3}$ College of Sciences, Beijing Institute of Technology, Beijing 100081, P.R. China \\ ${ }^{4}$ International College at Beijing, China Agricultural University, Beijing 100083, P.R. China \\ ${ }^{5}$ Hebei Daqing River Administrative Office, Hebei 071051, P.R. China \\ ${ }^{6}$ Baoding Bureau of Hydrology and Water Resources Survey, Hebei 071000, P.R. China \\ ${ }^{7}$ Baoding Meteorological Office, Hebei 071051, P.R. China
}

\begin{abstract}
Keeping water eco-environment health and virtuous circle of lake-wetland, and letting lakes recuperate and reproduce has become a common view all over the world. Although a great deal of research results were obtained, such as lake-wetland ecosystem management and eco-hydrological mechanism of eco-environment evolution, there are few researches about comprehensive analysis on evolution trend and driven mechanism of lake-wetland water eco-environment. Baiyangdian, the biggest grass-type lake-wetland in North China, was chosen as the research object in this paper. Based on the long-term and field observations of water environmental quality and analysis for remote sensing images of water ecological landscape pattern, the evolution trend and driving mechanism for water eco-environment of Baiyangdian in the past 60 years have been studied systematically. The results showed that the average annual water level fluctuated greatly with a decreasing tendency as a whole. During 1974 and 2007, there was a general pattern of land use types, which the emergent plants, water body and cultivated land were the main, and the residential area, forest land, grass land and unused land were distributed as flower arrangement state. During the periods, the water body and emergent plants areas were decreased respectively by $28.7 \%$ and $20.8 \%$, while the cultivated land areas were increased by $69.7 \%$. The main pollutants (NH4+-N, CODMn, BOD5, TP, and TN) concentrations in Baiyangdian Lake were changed greatly with spatiotemporal variation and the pollutant concentrations were increased obviously. In the three polluted regions (north zone, south zone, and
\end{abstract}

\footnotetext{
*Yunkai Li, Linyan Wang, Hua Zheng, Hai Jin and Tingwu Xu are equally contributed to this paper.

** Corresponding author.
} 
mixed zone), the north zone was polluted most seriously. The main pollutants concentrations were fluctuated obviously over a year, and the pollution was more serious in summer of normal and dry years, while the pollution was serious at the beginning of summer flood in wet years, and then became less. At last, the evolution trend and driven mechanism of water eco-environment of Baiyangdian was analyzed from three aspects, including typical climate indexes (such as precipitation, evaporation, air temperature, and solar radiation), ecological/environmental hydrology regime in upstream watershed of Baiyangdian, and human activities. It would provide some references to the comprehensive treatment of water eco-environment in Baiyangdian Lakes.

Keywords: Baiyangdian Lake, Water Eco-environment, Evolution Trend, Remote Sensing, Driven Mechanism.

\section{Introductions}

Lakes, natural or artificial, are important for human development and for the preservation of sound ecosystems and biodiversity on our planet. They contain 90 percent of the liquid freshwater on the earth's surface and are critical elements of the water cycle; they sustain aquatic biodiversity and provide livelihoods and social, economic, and aesthetic benefits that are essential for the quality of life in Lake Basin communities. However, under the circumstances of global climatic changes, industrialization and urbanization, the lake-wetland presents a good many ecological and environmental problems, such as reduced water surface, deteriorated water quality and destroyed water ecosystem, etc.[1] The management and protection of lake water eco-environment are facing severe challenges. To let lakes recuperate and multiply by rationally developing and utilizing lake-wetland resource, strengthening management and protecting of lake-wetland, maintaining lake-wetland water eco-environmental health, has become a common view all over the world[2] .

During the past century, a lot of research results about the forming process of lake-wetland ecosystem and its hydrological mechanism (including ecological/ environmental water requirement and water balance, dynamic changes of water level, water transfer, etc,) were obtained by all of the countries in the world [2], ant it has been become the main basis of managing lake-wetland resources. But on the whole, there are few researches about comprehensive analysis on evolution trend and driven mechanism of lake-wetland water eco-environment, which was centralized in the investigating research less than ten years, while the analytical results of evolution trend and driven mechanism of lake-wetland water eco-environment based on longtime locating monitoring are much less. Meanwhile, the complex relationship between lake-wetland ecological process and hydrological process, which not only relates to the development of wetland ecosystem itself, but also relates to ecological/environmental hydrological process of lakes upstream watershed, makes the evolving rule of each lake-wetland water eco-environment possess a certain common features as well as unique features. Therefore, it is necessary to comprehensively analyze evolution trend and driven mechanism for the water eco-environment of every typical lake-wetland. 
In this paper, Baiyangdian Lake was chose as the research object, which was the biggest grass-type lake-wetland in North China, to study systematically the evolution trend of lakes water eco-environment with long-term and field observations of water environmental quality and analysis for remote sensing images of water ecological landscape pattern. And the driven mechanism for water eco-environment from climatic changes and human activities was analyzed. It would be hoping for providing the references about the protection and ecological restoration of Baiyangdian Lake and even lake-wetland all over the world.

\section{General Situation of Baiyangdian Lake-Basin}

Baiyangdian Lake, which is located between $38^{\circ} 43^{\prime}-39^{\circ} 02^{\prime} \mathrm{N}$ and $115^{\circ} 38^{\prime}-116^{\circ} 07^{\prime} \mathrm{E}$ and the heartland of three cities Beijing, Tianjin, and Shijiazhuang, is the most representative grass-type lake-wetland in North China[3]. In addition, Baiyangdian Lake is likely to play an important role in the South-to-North Water Division Project under construction[4] .Baiyangdian Lake is located at the middle reaches of Daqing River, Haihe River Basin. And it controls a total area of 31, $199 \mathrm{~km}^{2}$, which accounts for $69.1 \%$ of the total area of the watershed. Baiyangdian Lake can be divided into four basin units according to river systems, including South Branch mountain area, North Branch mountain area, South Branch plain, and North Branch plain. Fig.1 showed that the distribution of Baiyangdian Lake and drainage basin water systems. Since ancient times, Baiyangdian Lake undertakes water from the south branch of Daqing-Zhaowang River (including Zhulong River, Xiaoyi River, Tang River, Fu River, Cao River, Baigouyin River, Pu River, and Ping River). The discharge is controlled by Zaolinzhuang regulation sluice and Shifangyuan Overflow Weir. It pours into sea via Zhaowangxin Canal, Duliujian River, and Beida Harbor[5].

Baiyangdian Lake watershed is located the monsoon climate of warm temperate area, which is hot and rainy in summer, cold and dry in winter. The lowest temperature is $-30.6^{\circ} \mathrm{C}$ and the highest is $43.5^{\circ} \mathrm{C}$, and average annual temperature is $7.3-12.7^{\circ} \mathrm{C}$, the average yearly accumulated temperature is $29.93-44.09^{\circ} \mathrm{C}$. The average annual precipitation in the whole watershed is $546.2 \mathrm{~mm}$, and the average annual evaporation is $1000-1200 \mathrm{~mm}$. Baiyangdian Lake borders the dykes, which is $39.5 \mathrm{~km}$ from east to west, $28.5 \mathrm{~km}$ from north to south, and the total area is about $365 \mathrm{~km}^{2}$. The main landscape of Baiyangdian Lake is water, the bottom of which is high in the west and low in the east, the altitude of it is $5.5-6.5 \mathrm{~m}$. The whole lake was divided to unequal and interrelated 143 sub-lakes with 3700 staggered channels. The tunable water storage capacity is $2.9 \times 10^{8} \mathrm{~m}^{3}$, water area accounts for about $50 \%$ [6]. Because of its special geographical position, Baiyangdian lake-wetland provides vital ecosystem service functions such as water conservation, water purification, regional climate regulation, species diversity maintenance, and so on. It plays an irreplaceable role in maintaining the ecological safety in North China, and is functioned as the "kidneys" of North China[5](Zhao,Cui, Yang,2005). 
With the affection of both climatic changes and human activities in the recent years, Baiyangdian Lake has been threatened by drought and pollution. The vegetation in upstream watershed becomes scarce and the function of water conservation is weak. Eco-environment problems appear, including frequent drying up, water pollution, the extinction of rare biological populations, etc.[7]. With the rapid degeneration of ecosystems, Baiyangdian Lake has changed from an exuberant lake to a lake facing shrink or even disappearance. The existence or disappearance of Baiyangdian Lake not only affects people's life and production, but also affects economic development and environmental balance of the North China Plain. The environment problems of Baiyangdian Lake have led to concerns of all circles in society, and the researchers have carried on a large amount of researches on eco-environment problems of Baiyangdian Lake[8], but few researches about comprehensive analysis on evolution trend and driving mechanism for water eco-environment of Baiyangdian Lake are reported.

\section{Materials and Methods}

\subsection{Monitoring on Water Quality and Water Level in Baiyangdian Lake}

The monitoring data about the water level of Baiyangdian Lake in the recent 60 years (1950-2008) were collected. The locations of the monitored spots were shown in Fig.1.

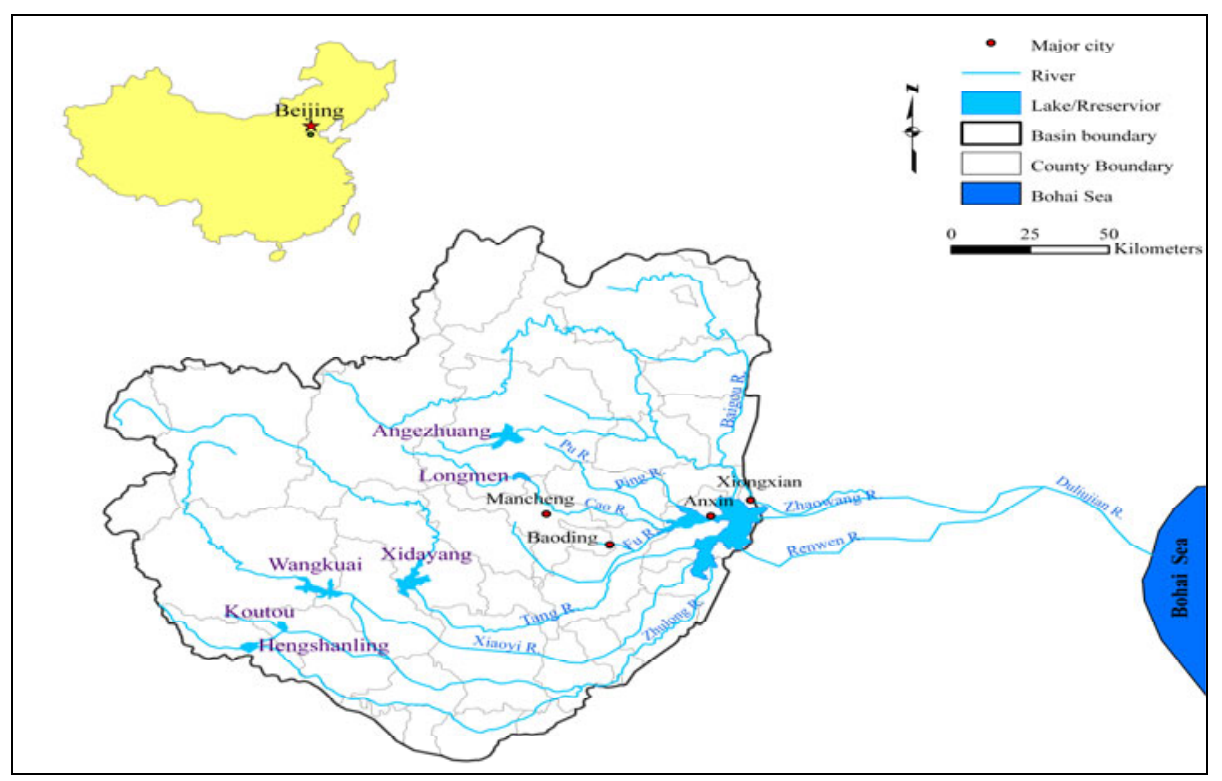

Fig. 1. Water System of Baiyangdian Lake and Its Upstream Watershed 


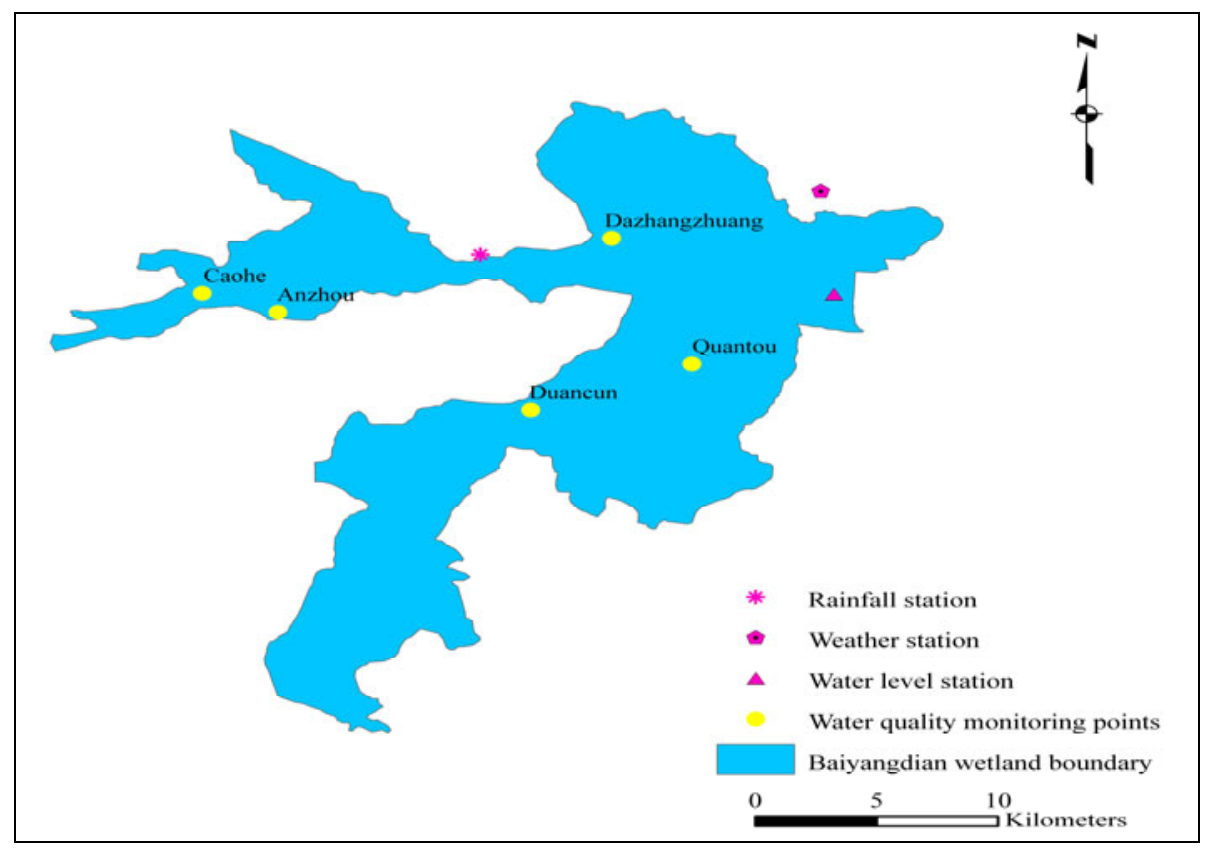

Fig. 2. Different Kinds of Monitoring Points

The pollutants in Baiyangdian Lake are from many sources, widely distributed, and constituted complexly. The main pollution indicators of water quality in Baiyangdian Lake are $\mathrm{NH}_{4}{ }^{+}-\mathrm{N}, \mathrm{COD}_{\mathrm{Mn}}$ (Chemical Oxygen Demand, Permanganate Index), $\mathrm{BOD}_{5}$ (Biochemical Oxygen Demand after 5 days ), TP (Total Phosphorus) and TN (Total Nitrogen). According to water sources and water flow characteristics in Baiyangdian Lake, it can be divided into three pollution zones, which is south pollution zone that undertakes water from south branch water system (mainly including Zhulong River, Xiaoyi River, and Tang River), north pollution zone that undertakes water from north branch water system (such as Fu River, Cao River, Baigouyin River, Bao River, Ping River, and so on), and mixed zone of the two pollution zone. The observation data $\left(\mathrm{NH}_{4}{ }^{+}-\mathrm{N}, \mathrm{COD}_{\mathrm{Mn}}, \mathrm{BOD}_{5}, \mathrm{TP}\right)$ of long time observation spots in the three zones from 1988 to 2008 were collected, including 1988 (restoration of water after the first drying up), 1991, 1994, 1996, 1999, and 2002-2008, the observation frequency was different from once per month to once per season; and each month's observation material of TN from 2002 to 2008. And the water quality monitoring data of the estuaries of Cao River and Fu River were collected, which was the most serious polluted location in North branch water system of Baiyangdian Lake watershed. The locations of water quality monitoring spots were shown in Fig.2. 


\subsection{Monitoring on Landscape Pattern of Water Ecosystem with Remote Sensing and Its Analysis Methods}

\subsubsection{Data Sources of Remote Sensing Images and Its Disposal Methods}

The Landsat MSS/TM remote sensing images of studied region were chosen as the data source, which was Sep. 3, 1974, Aug. 28, 1987 (Dried-up Year), Jul. 13, 1996 (Wet Year), and Aug. 24, 2007. The software ENVI 4.5 was used to modify atmosphere of the images, and the map of roads in Baiyangdian Lake basin with a scale of 1:100, 000 were used to carry on Geometric Calibration and Registration. Actuality Map of Land Use in 1983, Administrative Map, and DEM images were used to help interpret Baiyangdian Lake wetland landscape pattern, as well as to enhance the accuracy of interpreting land type. Referring to Technical Specification for Investigating the National Wetland Resources[9], and combining characteristics of Baiyangdian Lake landscape pattern and wetland evolving, Baiyangdian Lake landscape patterns can be divided into six kinds, which are: (1) Emergent plant, mainly including the distributing region of emergent plants (Reeds and shrub) and hygrophyte plants. (2) Water area, mainly including the submergent plants region, clean water region, and trenches. (3) Forest/grass land, mainly including the forest land, grass land and forest-grass mixed land. (4)Cultivated land, mainly including the regions of planting grain and cash crops. (5)Residential area. (6)Unused land.

\subsubsection{Image Disposal Methods Based on Support Vector Machine}

Support Vector Machine (SVM) theory and method was used to classify the images. SVM is a new study method, which was developed based on Statistical Learning Theory put forward by Vapnik at AT\&T Bell laboratory[10] . SVM, which can solve practical problems including small sample, nonlinearity, high dimension, local minimum point, has become a hot spot in machine learning area, and is successfully used in aspects such as classification and regression. According to the differences of the problems solved, SVM is called Support Vector Classification (SVC) and Support Vector Regression (SVR), respectively. The mechanism of SVC is to find an Optimal Hyperplane (OHP) which meets the demand of classification, in order to guarantee the accuracy of classification while not only classify the two kinds of data spots correctly as many as possible, but also make the blank area at the two sides of the Optimal Hyperplane the biggest - to make the classified two kinds of data spots farthest from classified plane[11]. SVC method was used to analyze the landscape classification of remote sensing images in this paper.

Given a training dataset $X=\left\{\left(x_{i}, y_{i}\right): x_{i} \in R^{n}, y_{i} \in\{+1,-1\}\right\}_{i=1}^{m}$, where each $x_{i}$ is labeled by $y_{i .}$ Linear SVM finds a boundary that separates two different classes of feature vectors with a maximum margin. It leads to the following convex quadratic programming problem:

$$
\min _{w, b} \frac{1}{2}\|w\|^{2}+C \sum_{i=1}^{m} \xi_{i}
$$




$$
\begin{array}{ll}
\text { s.t. } & y_{i}\left(w^{T} x_{i}+b\right) \geq 1-\xi_{i} \\
& \xi_{i} \geq 0, i=1,2, \ldots, m
\end{array}
$$

A nonlinear SVM projects feature vectors into a high dimensional feature space by using a kernel function such as a Gaussian kernel function $K\left(x_{i}, x_{j}\right)$. The linear SVM procedure is then applied to the feature vectors in this feature space. The corresponding dual quadratic programming to (1)-(3) for nonlinear SVM is as follows:

$$
\begin{gathered}
\min _{\alpha} \frac{1}{2} \sum_{i=1}^{m} \sum_{j=1}^{m} \alpha_{i} \alpha_{j} y_{i} y_{j} K\left(x_{i}, x_{j}\right)-\sum_{i=1}^{m} \alpha_{i} \\
\text { s.t. } \quad \sum_{i=1}^{m} y_{i} \alpha_{i}=0, \quad 0 \leq \alpha_{i} \leq C, i=1,2, \ldots, m
\end{gathered}
$$

where $C$ is a constant controlling the trade-off between maximizing the margin and minimizing the errors. After the determination of the solution $\alpha^{*}$ of (4)-(5) and $b^{*}$, we can get the decision function

$$
\left.f(x)=\operatorname{sgn}\left\{\sum_{i=1}^{m} \alpha_{i}^{*} y_{i} K x_{i}, x\right)+b^{*}\right\}
$$

where the function $\operatorname{sgn}$ is a sign function. If $x>0, \operatorname{sgn}(x)=1$; otherwise $\operatorname{sgn}(x)=-1$. In the present work, the Gaussian kernel function $K\left(x_{i}, x_{j}\right)=\exp \left\{-\left\|x_{i}-x_{j}\right\|^{2} / 2 \sigma^{2}\right\}$ is used. Because of the need to classify the lake-wetland to six landscape patterns, we extended this bi-class classification problem studied by SVM to the field of multi-class classification, and used bi-class classification machine which constructed $n(n-1) / 2$ to combine them together and realize n-class classification. In order to enhance classified accuracy of the research region, the optimal value of punishing factor $C$ and slack variable $\xi$ in SVM method were obtained by using LIBSVM process. The land use types of 516 points were investigated with GPS (The number of each landscape samples were almost the same), and it was divided two parts, which one half was used to form the training dataset, another one was used to calibrated the classification results combining the land use data in 1983. The results showed that the image classification was good, which the precision of image classification and Kappa index were over 0.92 and 0.88 , respectively.

\subsubsection{Analysis on Wetland Landscape Pattern and Its Dynamic Changes}

According to the characteristics of Baiyangdian Lake and research need ,a set of landscape pattern indexes were chose to reflect the changes of landscape structure and landscape pattern. The calculating formulae were as follows: 
(1) Landscape area index. Patch type area $(P A)$ : the total area of a certain landscape pattern.

Patch and landscape area ratio $(P R)$ : the percentage of a certain patch type accounts for the whole landscape area.

Patch number $(P N)$ : the total number of a certain patch type appears in the landscape.

(2) Landscape fragmentation index. Patch density $(P D)$ : the ratio of patch number and the total patch type area.

The average patch fractal dimension $\left(F R A C \_M N\right)$ : it reveals the relationship between shape and area of landscape constituted by patches, measures the complexity of the landscape shape and eco-process of the effect of landscape shape on the internal patches, and reflects the effect of human activity on landscape. The calculating formula is:

$$
F R A C_{-} M N=\frac{\sum_{i=1}^{m} \sum_{j=1}^{n}\left[\frac{2 \ln \left(0.25 P_{i j}\right)}{\ln \left(a_{i j}\right)}\right]}{N}
$$

where $a_{i j}$ is patch's area, $P_{i j}$ is the perimeter of landscape type, $N$ is the total number of patches.

(3) Landscape diversity index Shannon diversity index (SHDI): It reflects landscape heterogeneity and is sensitive to the Disequilibrium distribution condition of each patch type, which emphasizes on the contribution of rare patch type to information. The formula is:

$$
S H D I=-\sum_{i=1}^{m}\left[P_{i j} \ln \left(P_{i j}\right)\right]
$$

where, $P_{i}$ is the percentage of a certain patch type accounts for the whole landscape area.

(4) Landscape evenness index Shannon evenness index (SHEI): It reflects non-uniformity degree of each patch area distribution in landscape. It is represented by the ratio of diversity index and the maximum value. The formula is:

$$
S H E I=S H D I / / n N
$$

(5) Dynamic change index of landscape pattern Landscape type dynamic change index is the changing degree of a certain landscape type area per unit time. It can quantitatively characterize the changing speed of landscapes, which has a positive effect on comparing region differences of landscape type changing and predicting the changing tendency of landscape type in the future. The calculating formula is:

$$
K=\left(U_{b}-U_{a}\right) / U_{a} \times 1 / T \times 100 \%
$$


where $K$ is dynamic degree of a certain landscape type in the research period of time, $U_{a}$ and $U_{b}$ are the number of a certain landscape type at the beginning and in the end, respectively; $T$ is the length of the research time.

Transfer matrix of landscape is the area matrix and probability matrix of the transfer between different landscape types in a sequence unit, which not only reflects landscape type structures of different periods, but also reflects the condition of transfer between different land types. Transfer probability matrix can be calculated as follows:

$$
P_{i j}=A_{i j} / A
$$

where $0 \leq P_{i j} \leq 1$ and $\sum_{i=1}^{N} P_{i j}=1 \quad(i, j=1,2, \cdots, n), P_{i j}$ is the probability of transferring from type $i$ to type $j$ (from the beginning of the research to the end), $A_{i j}$ is the area transferring from type $i$ to type $j$ (from the beginning of the research to the end), $A$ is the area of type $i$ at the beginning of the research; $n$ is the number of landscape types.

\subsection{Meteorological Data}

The yearly and seasonal sequence observation data (including air temperature, solar radiation, evaporation) from 1956 to 2008 in Anxin county of Baoding City were collected, which is the location of Baiyangdian Lake. Yearly precipitation materials in Baiyangdian lake-wetland from 1956 to 2008 were also collected. The distribution of precipitation and weather stations were shown in Fig.2.

\section{Evolution Trend for Water Eco-Environment in the Past 60 Years}

\subsection{Dynamic Water Level in Lakes}

The ecological service functions of lake-wetland were closely correlated with the water level and water surface area, and the biodiversity and even the whole ecological function had great difference under different water lever conditions[12]. In the recent decades, the water level of Baiyangdian wetland has fluctuated greatly, and Fig.3 showed the annual average water level of Baiyangdian Lake observed by Shifangyuan in the recent 59 years (1950-2008). According to the result of Mann-Kendall significance testing, $\mathrm{U}=-4.96<0,|\mathrm{U}|=4.96>\mathrm{U}_{\alpha / 2}=2.32 \quad(\alpha=0.01)$, which meant that water level showed obvious decreasing tendency. For the recent 60 years, the water level in Baiyangdian fluctuated between drying up level (Lake drying up was defined as the observed water level by Shifangyuan Monitoring Site was lower than $6.5 \mathrm{~m})$ and $10.03 \mathrm{~m}$. From 1950s to the middle $1960 \mathrm{~s}$, the water level was high, and the lowest water level was $8.12 \mathrm{~m}$. Between 1965 and 1983, water level was between $6.37 \mathrm{~m}$ and $8.69 \mathrm{~m}$, and Baiyangdian Lake was dried up from 1984 to 1987(the gap in Fig.3). From 1988 to 2000, water level decreased significantly except the year 1991 and 1996. 
Baiyangdian Lake was dried up again in 2001 and 2002. The average water level from 2003 to 2008 was $7.04 \mathrm{~m}$, and $1.55 \mathrm{~m}$ lower than the average water level from 1950 to 1964 which was $8.99 \mathrm{~m}$.

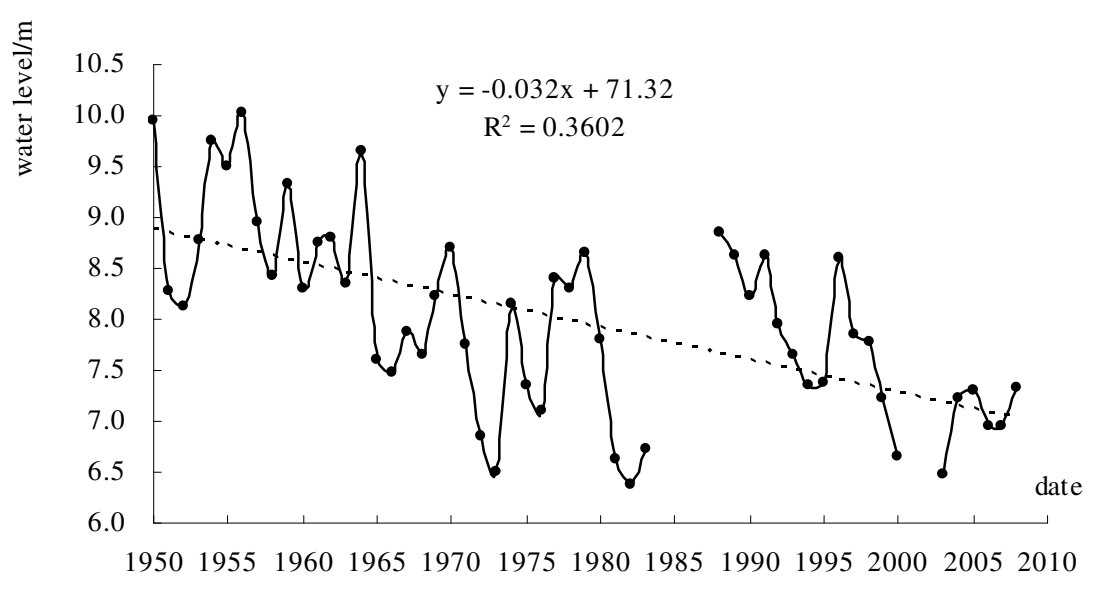

Fig. 3. Annual Average Water Level in Baiyangdian Lake between 1950 and 2008

\subsection{Space-Time Evolution Trend of Water Ecological Landscape Pattern}

Four remote sensing images were interpreted with ERDAS IMAGINE 8.7 and ENVI 4.5 software, and Fig. 4 showed the results. The wetland landscape pattern evaluating indexes at different time were calculated by using software ArcGIS 9.2 and Fragstat 3.3, and Tab.1 and Tab.2 showed the results.

From 1974 to 2007, there were large proportion of emergent plants, water body and cultivated land in Baiyangdian Lake, small proportion of residential area, forest land, grass land and unused land. The proportions of emergent plants in different years were $35.4 \%, 43.6 \%, 39.0 \%$, and $28.1 \%$ respectively. The proportions of water body were $31.1 \%, 7.3 \%, 31.4 \%$, and $22.2 \%$. The proportions of cultivated land were $24.7 \%$, $37.1 \%, 23.0 \%$, and $41.8 \%$ respectively. Generally speaking, the four landscape types, including emergent plants, water body, forest/grass land, and used land, showed a decreasing tendency in different degrees. Cultivated land and residential land increased significantly.

Emergent plants mainly changed to cultivated land and water body, change rate were $31.07 \%$ and $13.35 \%$, respectively. Water body mainly changed to emergent plants and cultivated land, change rate were $27.29 \%$ and $17.94 \%$, respectively. And changing phenomenon between water body and emergent plants existed because of the weather condition. Due to human activity, economical and social modernization, and the idea of the conversion of cropland to forest and grassland, cultivated lands mainly changed to forest, grassland, and residential land. The most violent change of landscape pattern happened from 1996 to 2007, the areas of emergent plant and water body decreased by $3984.8 \mathrm{hm}^{2}$ and $3371.4 \mathrm{hm}^{2}$ with the speed of $2.15 \% / \mathrm{a}$ and $2.26 \% / \mathrm{a}$, cultivated land 
increased by $6865.6 \mathrm{hm}^{2}$ with the speed of $6.28 \% / \mathrm{a}$; the most violent change of residential land happened from 1987 to 1996 , which increased by $437.3 \mathrm{hm}^{2}$ with the speed of $4.1 \% / \mathrm{a}$ in a decade.

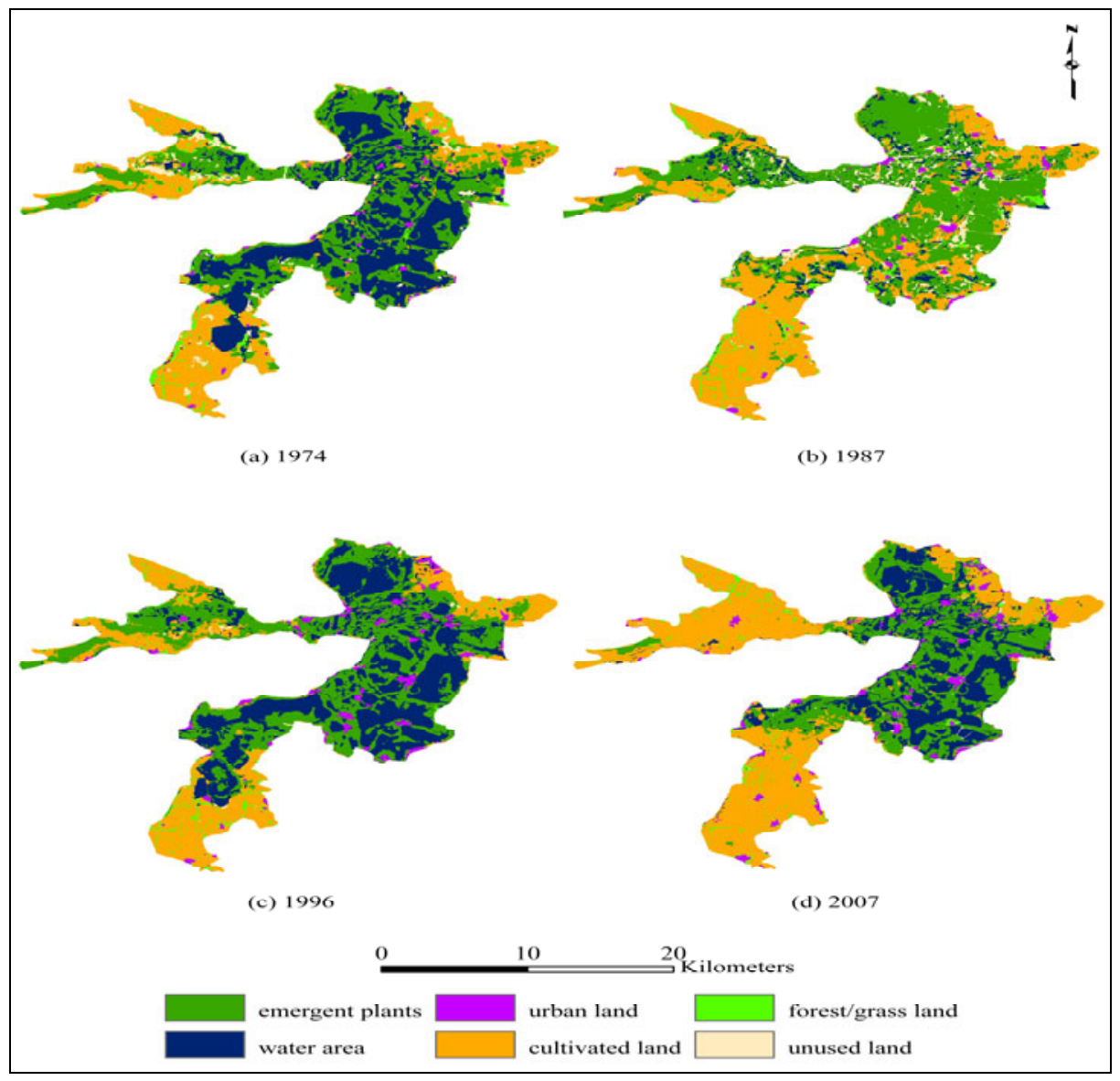

Fig. 4. Classification of Water Ecological Landscape Pattern in Baiyangdian Lake with Remote Sensing Monitoring

From landscape pattern evolving indexes listed in Tab.1, PN and PD had decreasing tendencies as a whole, which meant that heterogeneity of different landscape types decreased[13]. FRAC_MN showed a decreasing tendency, which indicated that landscape fragmentation degree increased and was more complex, suffered a tremendous influence from human factor, but had no significant difference[14]. In 1974, SHDI and SHEI in the research region were the biggest, which showed that landscape diversity degree was high in this period, heterogeneity was high, and dominance degree of patches in landscape was small; in 1987, SHDI and SHEI were the lowest, which meant that heterogeneity of different landscape types decreased, 
dominance degree increased, being in conformity with the fact of the sharp decrease of water area and the significant increase of emergent plants and cultivated land; from 1996 to 2007, SHDI and SHEI showed an increasing tendency, which indicated that landscape developed to diversity and uniformity, and embodied the tremendous effect of human activity in this period.

Table 1. Water Ecosystem Landscape Pattern Evaluating Indexes of Baiyangdian Lake in 1974-2007

\begin{tabular}{|c|c|c|c|c|c|c|c|c|c|c|c|}
\hline \multirow[b]{3}{*}{ Items } & \multirow{2}{*}{\multicolumn{6}{|c|}{$\begin{array}{c}\text { Patch level } \\
\mathrm{PA} / \mathrm{hm}^{2}(\mathrm{PR} / \%)\end{array}$}} & \multicolumn{5}{|c|}{ Landscape level } \\
\hline & & & & & & & $\mathrm{PN}$ & $\mathrm{PD}$ & FRAC_MN & SHDI & SHEI \\
\hline & $\begin{array}{c}\text { Emergent } \\
\text { plants }\end{array}$ & $\begin{array}{l}\text { Water } \\
\text { area }\end{array}$ & $\begin{array}{c}\text { Cultivated } \\
\text { land }\end{array}$ & $\begin{array}{c}\text { Forest/grass } \\
\text { land }\end{array}$ & $\begin{array}{l}\text { Urban } \\
\text { land }\end{array}$ & $\begin{array}{l}\text { Unused } \\
\text { land }\end{array}$ & /in & $\mathrm{d} / \mathrm{s}$ & & & \\
\hline 1974 & $\begin{array}{c}12928.2 \\
(35.4)\end{array}$ & $\begin{array}{c}11355.4 \\
(31.1)\end{array}$ & $\begin{array}{l}8999.6 \\
(24.7)\end{array}$ & $\begin{array}{c}1643.2 \\
(4.5)\end{array}$ & $\begin{array}{l}582.3 \\
(1.6)\end{array}$ & $\begin{array}{l}998.8 \\
(2.7)\end{array}$ & 20109 & 0.55 & 1.10 & 1.37 & 0.77 \\
\hline 1987 & $\begin{array}{c}15923.4 \\
(43.6)\end{array}$ & $\begin{array}{c}2662.7 \\
(7.3)\end{array}$ & $\begin{array}{c}13531.8 \\
(37.1)\end{array}$ & $\begin{array}{c}1527.8 \\
(4.2)\end{array}$ & $\begin{array}{l}820.4 \\
(2.3)\end{array}$ & $\begin{array}{c}2041.4 \\
(5.6)\end{array}$ & 23560 & 0.65 & 1.08 & 1.29 & 0.72 \\
\hline 1996 & $\begin{array}{c}14228.6 \\
(39.0)\end{array}$ & $\begin{array}{c}11462.8 \\
(31.4)\end{array}$ & $\begin{array}{l}8406.9 \\
(23.0)\end{array}$ & $\begin{array}{c}1005.1 \\
(2.8)\end{array}$ & $\begin{array}{c}1257.7 \\
(3.5)\end{array}$ & $\begin{array}{l}146.2 \\
(0.4)\end{array}$ & 19894 & 0.54 & 1.09 & 1.31 & 0.73 \\
\hline 2007 & $\begin{array}{c}10243.8 \\
(28.1)\end{array}$ & $\begin{array}{l}8091.4 \\
(22.2)\end{array}$ & $\begin{array}{c}15272.5 \\
(41.8)\end{array}$ & $\begin{array}{c}1283.2 \\
(3.5)\end{array}$ & $\begin{array}{c}1490.1 \\
(4.1)\end{array}$ & $\begin{array}{l}126.5 \\
(0.4)\end{array}$ & 19788 & 0.54 & 1.08 & 1.32 & 0.74 \\
\hline
\end{tabular}

Table 2. Transfer Probability Matrix of Water Ecosystem Landscape Pattern in Baiyangdian Lake (1974-2007) (\%)

\begin{tabular}{cccccccc}
\hline $\begin{array}{c}\text { Landscape } \\
\text { types }\end{array}$ & $\begin{array}{c}\text { Dynamic } \\
\text { dgree }\end{array}$ & $\begin{array}{c}\text { Emergent } \\
\text { plants }\end{array}$ & Water & Cultivated & Forest/grass & Urban & Unused \\
land & land & land & land \\
Emergent plants & -1.60 & 50.4 & 27.29 & 4.75 & 6.55 & 2.61 & 9.9 \\
Water area & -2.21 & 13.35 & 51.36 & 3.49 & 7.14 & 5.69 & 4.42 \\
Cultivated land & 5.36 & 31.07 & 17.94 & 81.16 & 69.18 & 12.74 & 76.21 \\
Forest/grass land & -1.69 & 2.23 & 1.47 & 5.46 & 8.84 & 9.16 & 6.22 \\
Urban land & 11.99 & 2.66 & 1.57 & 4.89 & 7.87 & 69.44 & 2.93 \\
Unused land & -6.72 & 0.28 & 0.37 & 0.25 & 0.42 & 0.37 & 0.32 \\
\hline
\end{tabular}

\subsection{Spatiotemporal Variation of Water Environmental Quality}

From 1960s, because of self-purification capability decreased for water source deficiency and the effect of human activity, large amount of wastewater had flown into Baiyangdian Lake, which made the water environmental quality worse day by day[15] Fig.5 showed the dynamic changes of $\mathrm{NH}_{4}{ }^{+}-\mathrm{N}, \mathrm{COD}_{\mathrm{Mn}}, \mathrm{BOD}_{5}, \mathrm{TP}, \mathrm{TN}$ in 
south pollution zone, north pollution zone, and mixed pollution zone from 1988 to 2008. From it, we can find that North pollution zone was polluted most seriously in the three pollution zones, where the concentrations of $\mathrm{NH}_{4}{ }^{+}-\mathrm{N}$ and $\mathrm{COD}_{\mathrm{Mn}}$ in 1994 and 1999-2008 were worse than water of Grade V. The concentrations of them were the highest in 2004, where the concentration of $\mathrm{NH}_{4}{ }^{+}-\mathrm{N}$ was 16 times the water quality standard of Grade $\mathrm{V}(2 \mathrm{mg} / \mathrm{L})$, and the concentration of $\mathrm{COD}_{\mathrm{Mn}}$ was 2.2 times the water quality standard of Grade V $(15 \mathrm{mg} / \mathrm{L})$. The concentrations of $\mathrm{BOD}_{5}$ increased obviously from 1999 to 2005, worse than water quality standard of Grade V (10mg/L). The concentrations of TP were mostly between $0.2 \mathrm{mg} / \mathrm{L}$ and $1.8 \mathrm{mg} / \mathrm{L}$, which were higher than surface water quality standard of Grade V $(0.2 \mathrm{mg} / \mathrm{L})$. After the largest concentration in 1999, it showed a decreasing tendency. The concentrations of TN fluctuated obviously, which were 2 to 18 times the water quality standard of Grade V $(2.0 \mathrm{mg} / \mathrm{L})$ each year, but generally showed a decreasing tendency. On the whole, the water quality of north pollution zone was at a worse than Grade V.

The pollution degree of south pollution zone was lower than that of north pollution zone, except that the TP and TN concentrations were comparatively higher, and the TP concentrations met the water quality standard of Grade V from 1999 to 2008, and the TN concentrations were worse than water quality standard of Grade V. The $\mathrm{NH}_{4}{ }^{+}-\mathrm{N}$ concentrations were mostly between $0.15 \mathrm{mg} / \mathrm{L}$ and $1.0 \mathrm{mg} / \mathrm{L}$, which met the water quality standard of Grade III. The $\mathrm{COD}_{\mathrm{Mn}}$ concentrations were mostly between $2 \mathrm{mg} / \mathrm{L}$ and $10 \mathrm{mg} / \mathrm{L}$, which were better than water quality standard of Grade IV. The $\mathrm{BOD}_{5}$ concentration were within water quality standard of Grade IV $(6 \mathrm{mg} / \mathrm{L})$ before 1999 , and increased to the concentrations between the water quality standard of Grade IV-V. The $\mathrm{NH}_{4}{ }^{+} \mathrm{N}$ concentration in mixed pollution zone was affected by the pollution of both north and south pollution zone. But due to the affect of water body dilution in Baiyangdian Lake and the removal function of plants, which was decreased along the water movement path, the $\mathrm{NH}_{4}{ }^{+}-\mathrm{N}$ concentration was lower than both of the other two pollution zones.

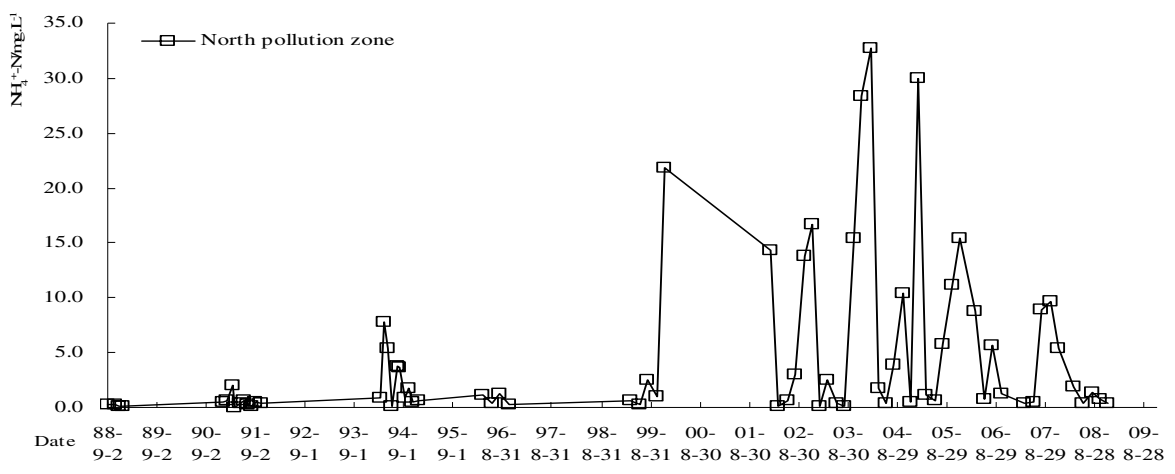

Fig. 5. Annual Pollutants Concentrations Dynamics 

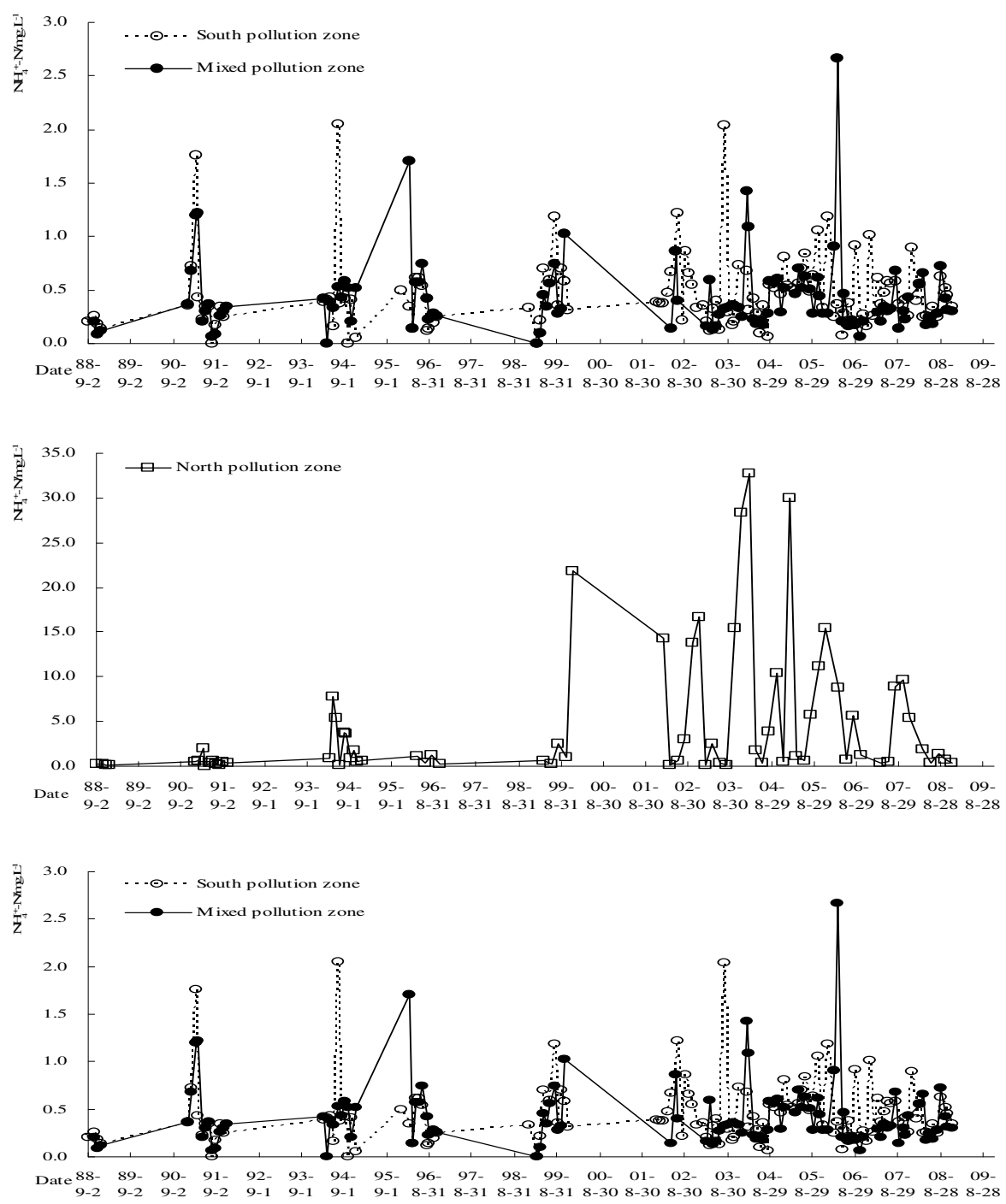

(a) $\mathrm{NH}_{4}{ }^{+}-\mathrm{N}$

Fig. 5. (Continued) 

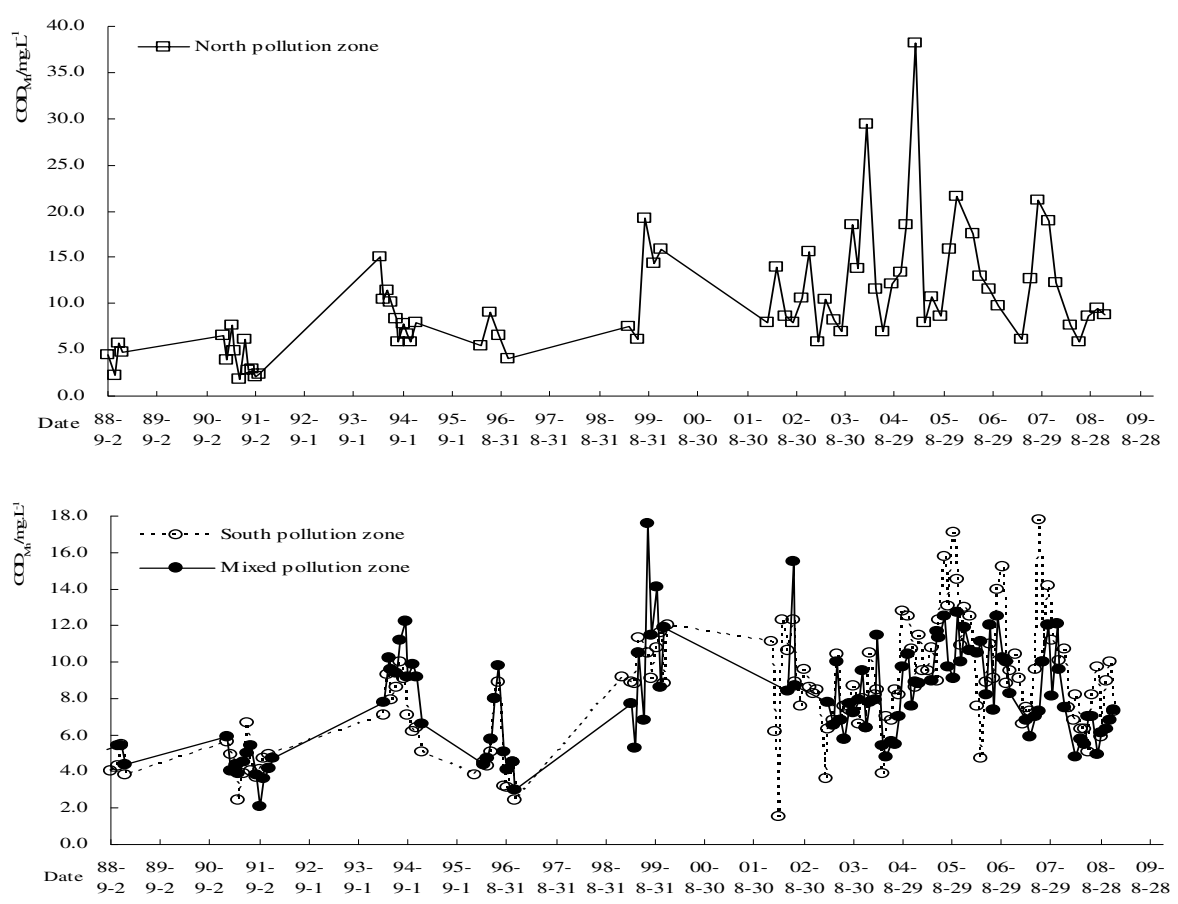

(b) $\mathrm{COD}_{\mathrm{Mn}}$

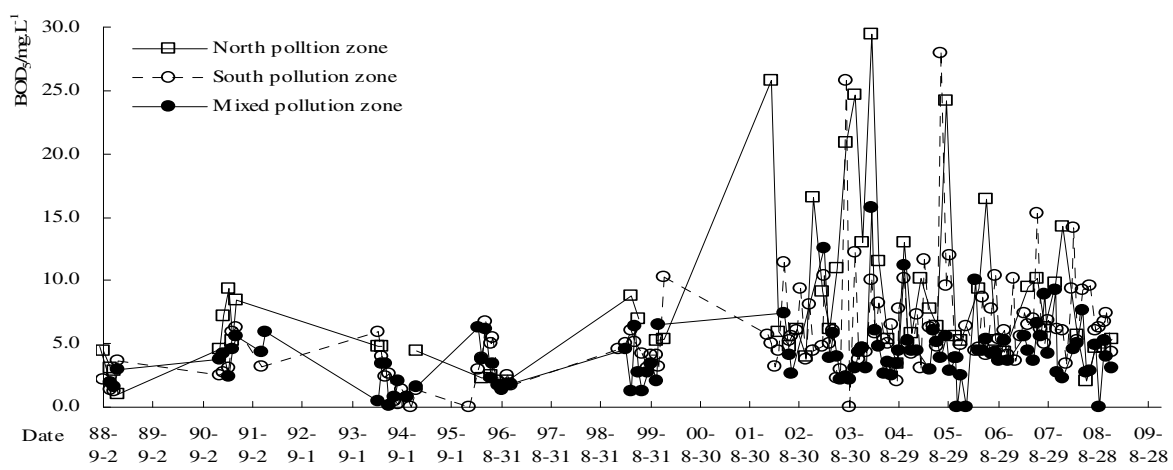

(c) $\mathrm{BOD}_{5}$

Fig. 5. (Continued) 


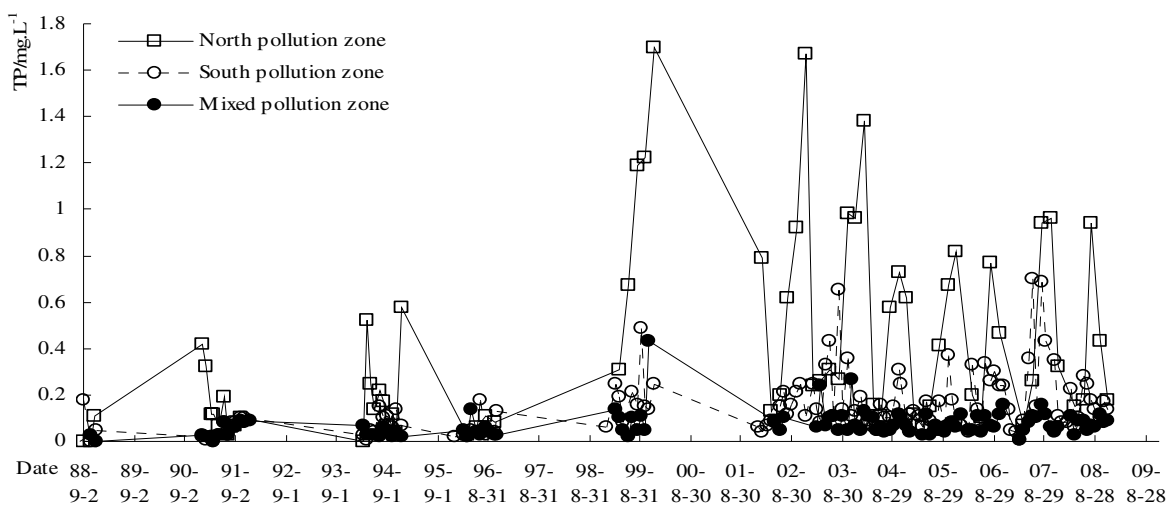

(d) $\mathrm{TP}$

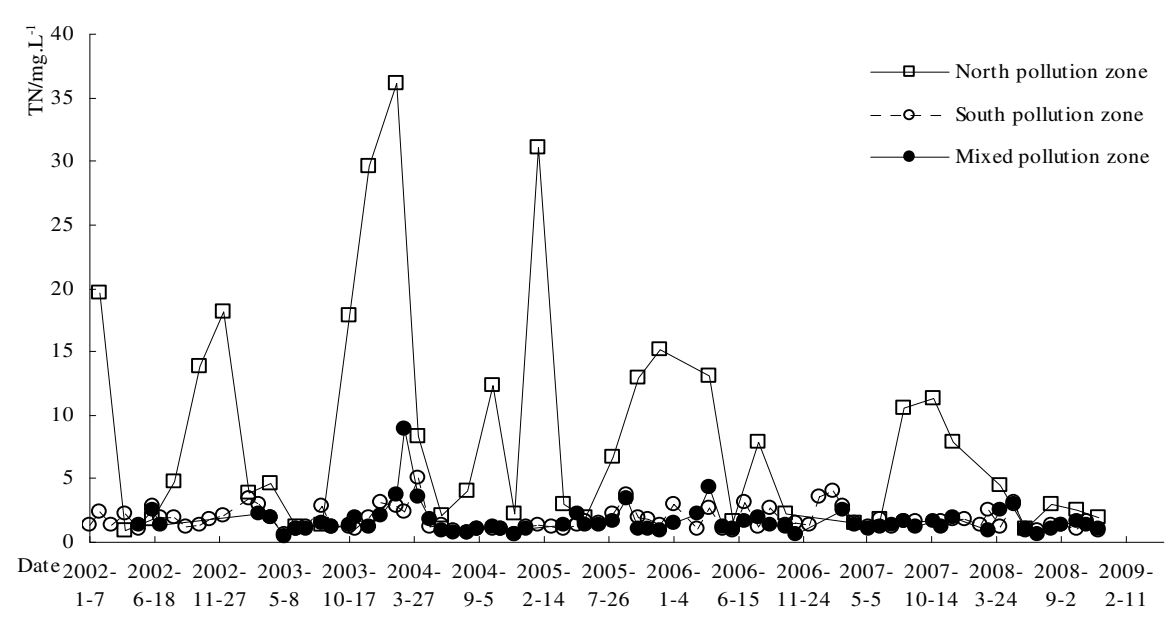

(e) $\mathrm{TN}$

Fig. 5. (Continued)

Generally speaking, the concentrations of pollutants in different years fluctuated greatly from 1988, in which Baiyangdian Lake was refilled. The increasing of the concentrations of $\mathrm{NH}_{4}{ }^{+}-\mathrm{N}, \mathrm{COD}_{\mathrm{Mn}}, \mathrm{BOD}_{5}$, and $\mathrm{TP}$ were obvious, the TN concentration showed a decreasing tendency as a whole. Meanwhile, the main pollutants concentrations fluctuated obviously in a year. In normal and dry years, the pollution was more serious in summer, while the pollution was serious at the beginning of summer flood in wet years and then became less. It was the reason that upper regions of rivers were almost no flow and large amounts of pollutants stored in the rivers flowed into Baiyangdian Lake with the initial flood. For instance, a great flood occurred in 1996, the flood brought a large amount of pollutants in rivers at the beginning which caused the pollutants ( 
later with the increasing of water flowing into Baiyangdian Lake, the dilution function of river water emerged, which caused the pollutants concentrations decreased.

\section{Analysis on Driving Mechanism of Water Eco-Environment Evolution}

\subsection{Climatic Changes in Baiyangdian Lake}

\subsubsection{Precipitation}

Precipitation, as one of the main ways to income water in Baiyangdian Lake, had a vital effect on the evolution of water eco-environment. Average annual precipitation was $514.1 \mathrm{~mm}$ in lake, and Fig. 6 showed the results of precipitation in lake from 1974 to 2008. From it, we can find that the annual precipitation in Baiyangdian Lake changed greatly and the largest precipitation from 1955 to 2008 were 909mm (in 1996), 3.6 times as much as the smallest annual precipitation $252 \mathrm{~mm}$ (in 1997). The precipitation showed a slow decreasing tendency before 1980s, while, the precipitation decreased rapidly after 1980s. It was present the phenomenon of obvious continuous wet and dry year. For instance, it was dry year occurred from 1983 to 1987 for five years, which directly caused Baiyangdian Lake dried up with a duration of 1650 days.

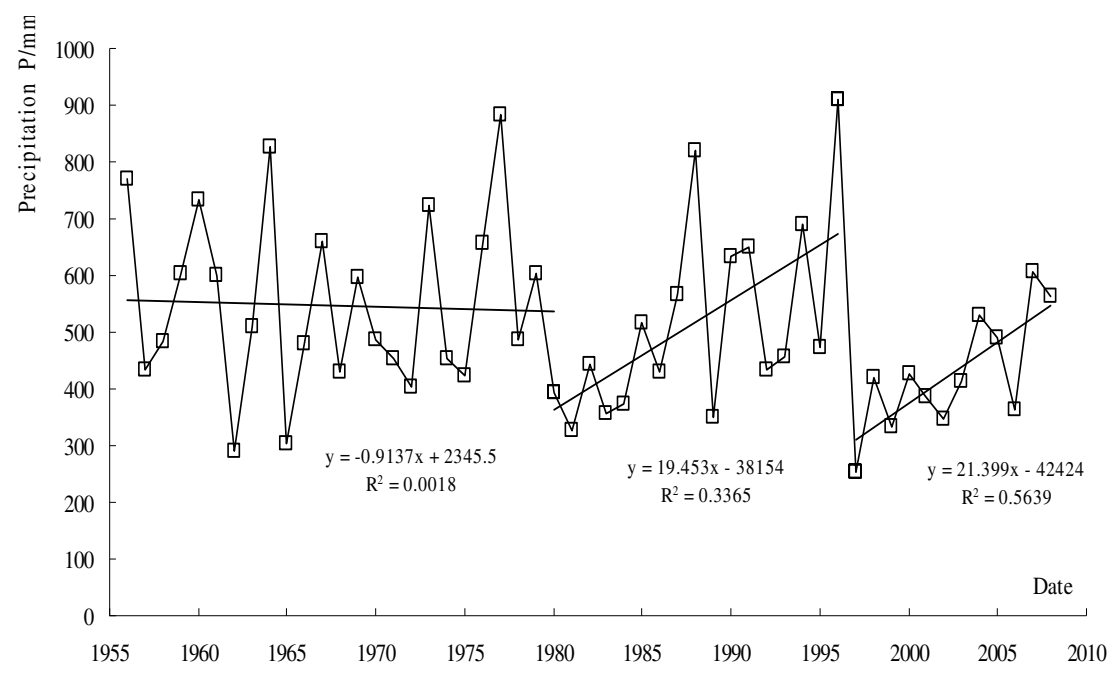

Fig. 6. Annual Precipitations of Baiyangdian Lake

\subsubsection{Evaporation}

Fig.7 and Fig.8 showed the results of evaporation in Baiyangdian Lake. The annual average evaporation in Baiyangdian was $1303.6 \mathrm{~mm}$, this was 2.5 times the annual average precipitation. In the early 1970s, annual average evaporation with 10-year running means was $1289.0 \mathrm{~mm}$, and decreased continuously. The lowest evaporation value was in the early 1990s, and then increased gradually to $1347.1 \mathrm{~mm}$ in 2004 . 
We can see that, in the recent 30 years, water evaporation in Baiyangdian Lake has showed a increasing tendency which decreased at first and increased later. The significance test in Tab.6 also verified that the evaporation of Baiyangdian Lake showed a increasing tendency.

According to Fig.7, Fig.8, and the Mann-Kendall significance test in Tab.3, evaporation of different seasons except autumn in Baiyangdian showed unobvious increasing tendency, which passed the confidence level of 99\%. The evaporation in summer increased the largest, which was $31.40 \mathrm{~mm}$ more than that of $1970 \mathrm{~s}$, and then was spring more $17.36 \mathrm{~mm}$ than that of $1970 \mathrm{~s}$. The increase of air temperature would enhance evaporation capacity, so the increasing continuously temperature was the main impact factor caused the water surface shrinked[7].

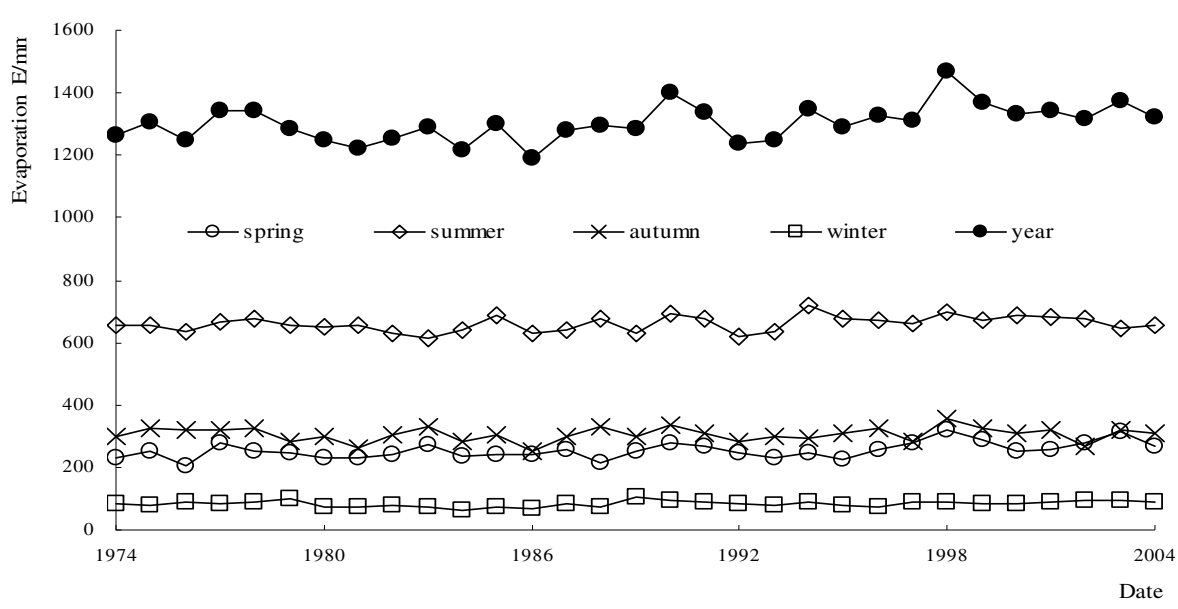

Fig. 7. Seasonal and Years Evaporations of Baiyangdian

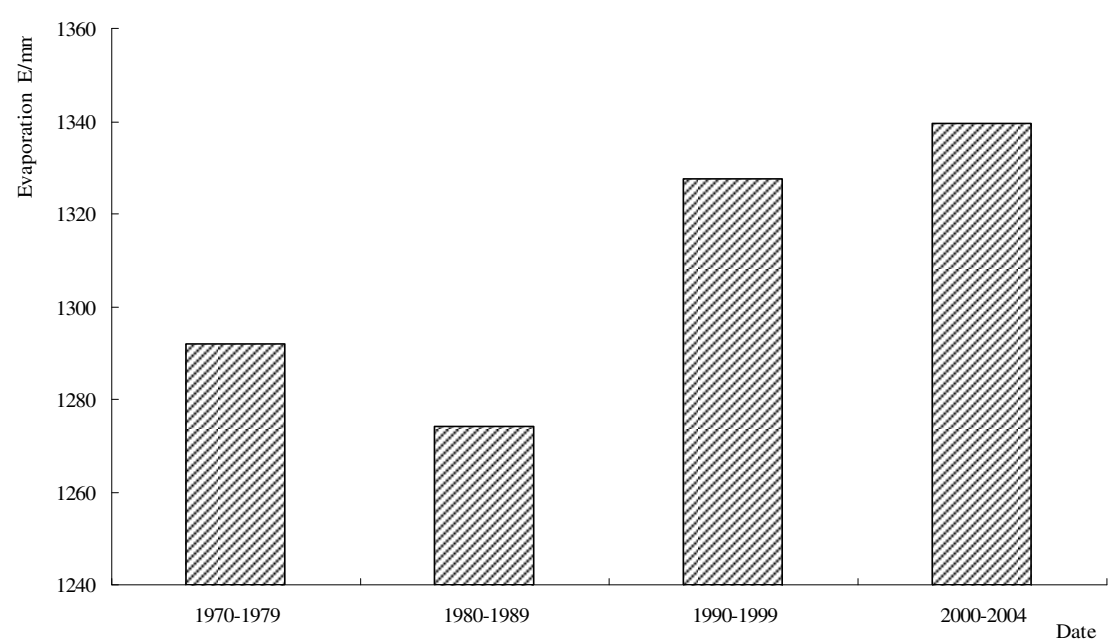

Fig. 8. Ten Yearly Evaporations of Baiyangdian 


\subsubsection{Air Temperature}

Annual average air temperature in Baiyangdian was $12.42^{\circ} \mathrm{C}$. Fig. 9 and Fig. 10 showed air temperature dynamic changes under three time scales of seasonally, yearly and ten-yearly, respectively, and Tab.3 showed the results of Mann-Kendall significance test. The result showed that annual average temperatures with 10-year running means in Baiyangdian Lake were increased and then decreased tendency in the past over 30 years. The annual average temperature in the $1980 \mathrm{~s}$ was $0.13^{\circ} \mathrm{C}$ higher than that of the 1970s. From the 1990s, the air temperature increased greatly, and the annual average temperature was $0.38^{\circ} \mathrm{C}$ higher than that of 1970s. After 2000, the air temperature decreased, and the annual average temperature equal to the temperature of 1970 s.

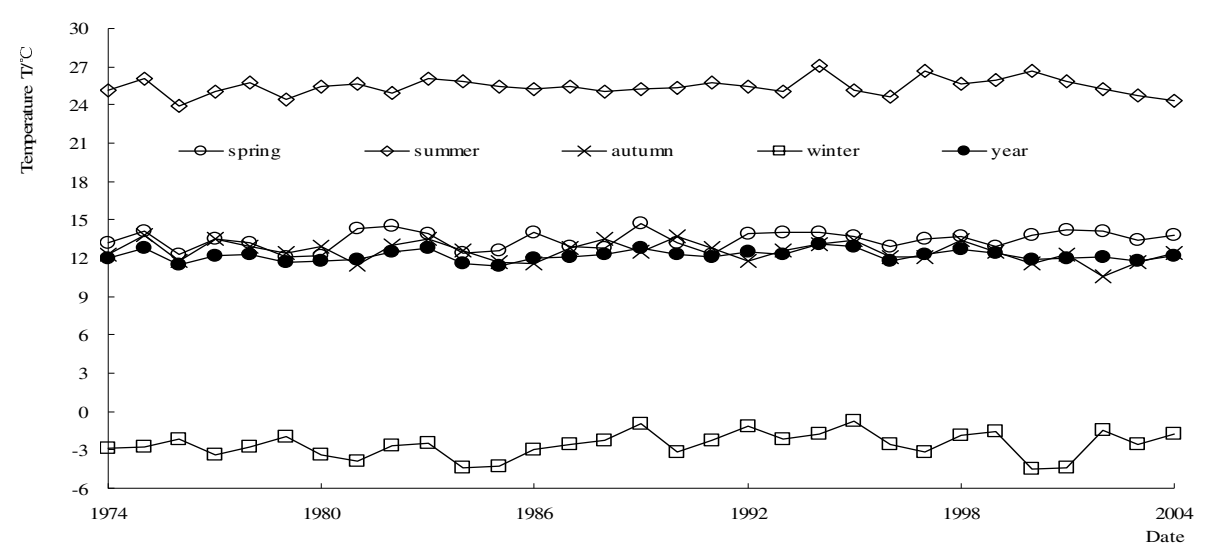

Fig. 9. Seasonal and Years Average Temperatures in Baiyangdian Lake

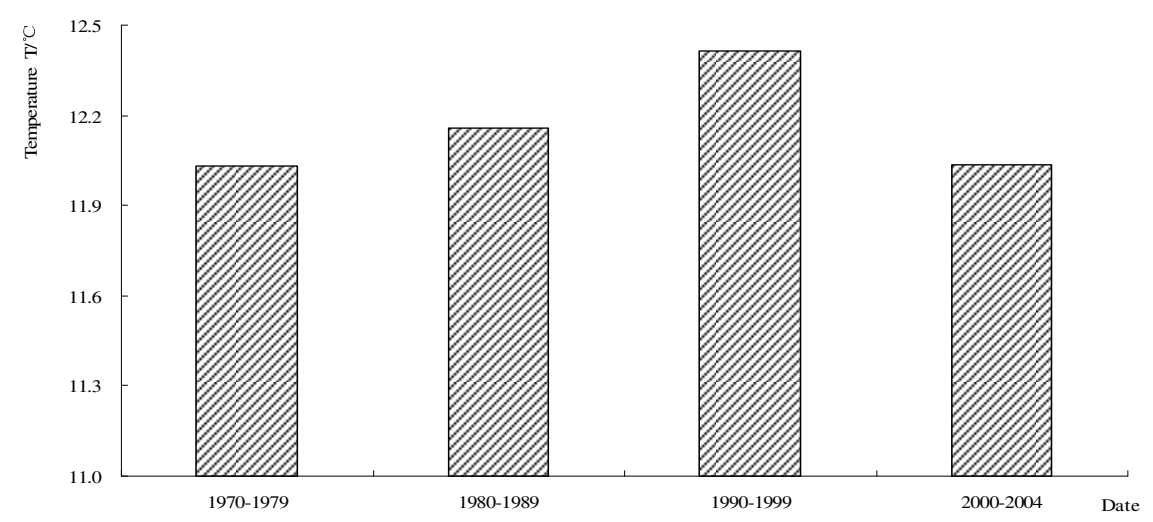

Fig. 10. Ten Yearly Average Temperatures in Baiyangdian 
Temperature changes of different seasons also showed obvious increasing tendency, which was more obvious in spring and winter. The average temperature in spring after the year 2000 was $0.94^{\circ} \mathrm{C}$ higher than that of $1970 \mathrm{~s}$, and the average temperature in winter after the year 2000 was $0.21^{\circ} \mathrm{C}$ higher than that of $1970 \mathrm{~s}$. The increase of temperature would cause all kinds of hydrological variables (such as the decreasing of precipitation, the increasing of soil temperature, the increasing of agricultural water consumption, and so on) changed, directly or indirectly caused the degeneration of Baiyangdian lake-wetland.

\subsubsection{Solar Radiation}

Fig.11 and Fig.12 showed solar radiation dynamic changes under three time scales of seasonal, yearly and ten-yearly, respectively. Tab.3 showed the results of Mann-Kendall significance test. The result showed that solar radiation always had existed a decreasing tendency in the past 30 years. The daily average solar radiation was $14.2 \mathrm{MJ} /\left(\mathrm{m}^{2} \cdot \mathrm{d}\right)$ in the $1970 \mathrm{~s}$, and decreased to $14.0 \mathrm{MJ} /\left(\mathrm{m}^{2} \cdot \mathrm{d}\right)$ in $1980 \mathrm{~s}$, $12.8 \mathrm{MJ} /\left(\mathrm{m}^{2} \cdot \mathrm{d}\right)$ in $1990 \mathrm{~s}$. The daily average solar radiation decreased a bit from the year 2000 to 2008 , to $12.7 \mathrm{MJ} /\left(\mathrm{m}^{2} \cdot \mathrm{d}\right)$. According to the Mann-Kendall test, solar radiation of different seasons also showed obvious decreasing tendency, which was more obvious in summer and winter. The solar radiation in summer after the year 2000 was $2.09 \mathrm{MJ} /$ $\left(\mathrm{m}^{2} \cdot \mathrm{d}\right)$ lower than that of $1970 \mathrm{~s}$, and the solar radiation in winter after the year 2000 was $1.64 \mathrm{MJ} /\left(\mathrm{m}^{2} \cdot \mathrm{d}\right)$ lower than that of $1970 \mathrm{~s}$.

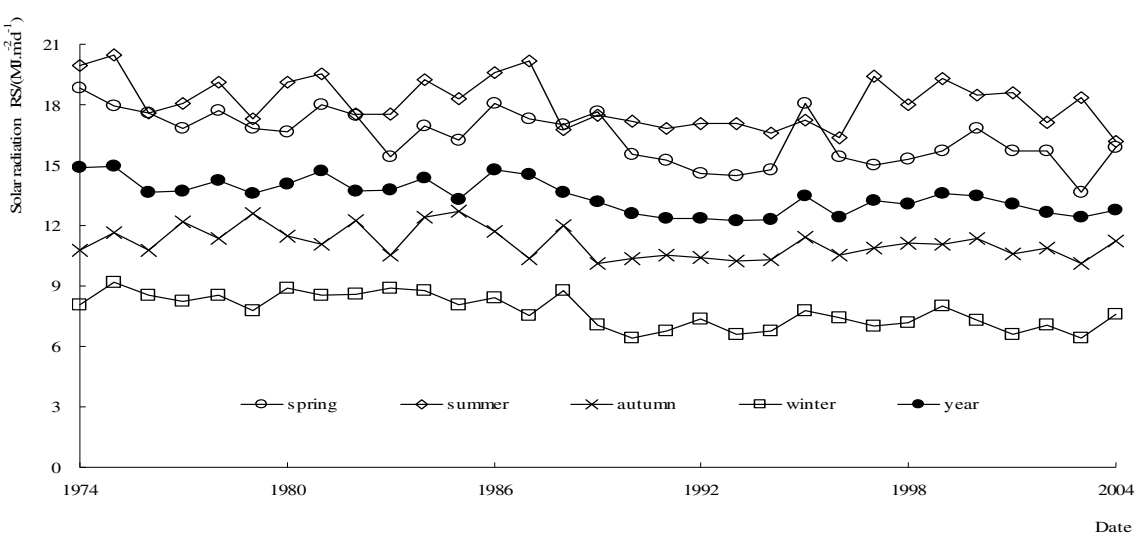

Fig. 11. Seasonal and Years Average Daily Solar Radiation in Baiyangdian Lake 


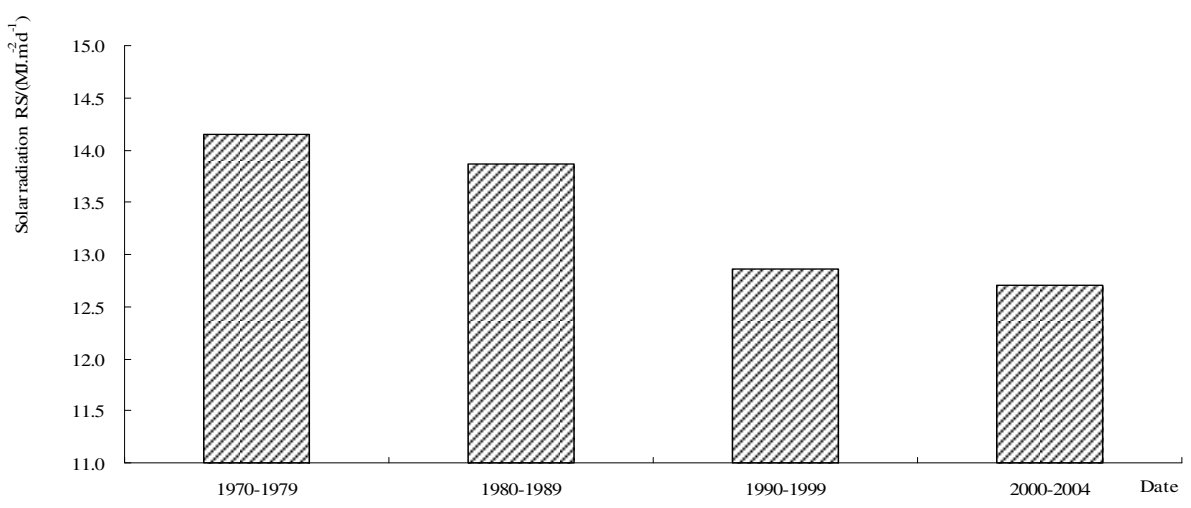

Fig. 12. Ten Years Average Daily Solar Radiation in Baiyangdian Lake

Table 3. Mann-Kendall Test Results of Yearly Evaporation, Air Temperature and Solar Radiation

\begin{tabular}{cccc} 
& & \\
& & & \\
Meteorological factors & & & \\
\hline Year & 1.30 & $4.08^{* *}$ & $-4.63^{* *}$ \\
Spring & 1.50 & $3.40^{* *}$ & $-2.33^{*}$ \\
Summer & 1.19 & 0.38 & $-3.44^{* *}$ \\
Autumn & $3.37^{* *}$ & 0.62 & $-3.19^{* *}$ \\
Winter & 1.07 & $3.95^{* *}$ & $-4.20^{* *}$ \\
\hline
\end{tabular}

Note: * Correlation is significant at the 0.10 level(2-tailed),

** Correlation is significant at the 0.01 level(2-tailed).

\subsubsection{Relationship between the Local Climate and Water Level in Lake}

Water level and meteor -ological factors of each year were carried on correlation analysis, the results of which were shown in Tab.4. The result showed that there was obvious positive correlation between water level and precipitation, the relativity of which was 0.483 . And the water level showed negative correlation with temperature and evaporation, the relativity of which were 0.326 and 0.314 , respectively. Water level and solar radiation were little related. Therefore, precipitation had a vital effect on the changes of Baiyangdian Lake eco-environment. 
Table 4. Relativity between Water Level and Meteorological Factors

\begin{tabular}{ccccc}
\hline Pearson correlation & Precipitation & Air temperature & Evaporation & Solar radiation \\
\hline Water level & $0.483^{* *}$ & -0.326 & -0.314 & -0.008 \\
\hline
\end{tabular}

Annotation: " Correlation is significant at the 0.01 level(2-tailed).

\subsection{Human Activity}

\subsubsection{Eco-Hydrological Process in Upstream Watershed Changed Greatly, Directly Causing the Runoff into Lake Decreased Sharply}

Watersheds are the source of lakes, and lakes are the converging of watersheds. Watersheds and lakes form a dynamic system which shows mutual feedback and close relationship between nature and society. At present, most of the researches on lakes and watersheds studied them respectively, which ignored the integrality of watershed hydrological process and ecosystem. The emphasis of some researches on lake water environment had already transferred to complicated lake-watershed macro-system, from watershed scale to carry through pollution prevention and cure, ecologic recovery, and ecosystem management. The changed eco-hydrological process in upstream watershed had significant effect on Baiyangdian lake-wetland.

The water storage of Baiyangdian Lake mainly relied on runoff formed by the precipitation in upstream watershed, which flowed into Baiyangdian through rivers. Runoff into Baiyangdian Lake in 1950s was abundant, but after the year 1958, 6 large reservoirs (Hengshanling, Koutou, Wangkuai, Xidayang, Longmen, and Angezhuang), 12 medium-sized reservoirs, and 116 small reservoirs were constructed in the upstream watershed in succession. The reservoirs controlled $54.93 \%$ of the watershed area in

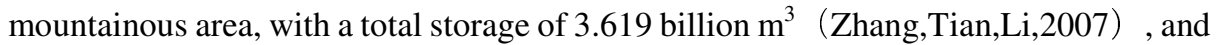
had vital effect on intercepting the runoff from the upstream watershed. The building of water conservancy projects caused water flowing into Baiyangdian Lake decreased. In wet year, the runoff into Baiyangdian was abundant; in normal year, the control coefficient of reservoirs to runoff was $60 \%$; while in dry year, the water in the reservoirs was mostly used for agricultural irrigation and little water was left, control coefficient to runoff was $96 \%$.

The serious problems of Baiyangdian Lake, including resources water shortage, water quality-induced water shortage, unbalanced ecosystem, had attracted much attention from state council, ministry of water resources, Haihe River Commission, leaders and experts from departments in Hebei province. Deficiency of water was gradually acknowledged as the bottleneck of the Baiyangdian Lake eco-environmental management [16]. In order to ease this situation, water was refilled to Baiyangdian

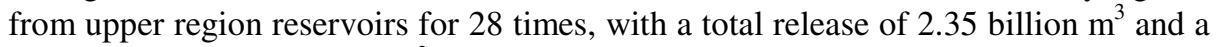
total refill of 1.09 billion $\mathrm{m}^{3}$ water to Baiyangdian Lake, and Table 5 showed the results. From it, we can find that Baiyangdian Lake had changed from a natural controlled lake-wetland to a totally artificial regulated lake. 
Table 5. Situation of Different Reservoirs Supplying Water to Baiyangdian Lake

\begin{tabular}{|c|c|c|c|c|c|c|c|c|c|}
\hline Year & Times & $\begin{array}{c}\text { Water } \\
\text { supplement } \\
\text { source }\end{array}$ & $\begin{array}{c}\text { Released } \\
\text { water } \\
\left(\text { million } \mathrm{m}^{3}\right)\end{array}$ & $\begin{array}{c}\text { Water flowing } \\
\text { into } \\
\text { Baiyangdian } \\
\left(\text { million } \mathrm{m}^{3}\right)\end{array}$ & Year & Times & $\begin{array}{c}\text { Water } \\
\text { supplement } \\
\text { source }\end{array}$ & $\begin{array}{c}\text { Released } \\
\text { water } \\
\left(\text { million } \mathrm{m}^{3} \text { ) }\right.\end{array}$ & $\begin{array}{c}\text { Water } \\
\text { flowing } \\
\text { into } \\
\text { Baiyangdiar } \\
\left(\text { million } \mathrm{m}^{3}\right)\end{array}$ \\
\hline \multirow{5}{*}{1983} & 1 & $\begin{array}{c}\text { Angezhuang } \\
\text { reservoir }\end{array}$ & 25.07 & 9.79 & \multirow{3}{*}{2001} & 16 & $\begin{array}{c}\text { Angezhuang } \\
\text { reservoir }\end{array}$ & 50.87 & 21.64 \\
\hline & 2 & $\begin{array}{r}\text { Xidayang } \\
\text { reservoir }\end{array}$ & 11.23 & 4.51 & & 17 & $\begin{array}{r}\text { Wangkuai } \\
\text { reservoir }\end{array}$ & 100.79 & 45.13 \\
\hline & 3 & $\begin{array}{r}\text { Xidayang } \\
\text { reservoi }\end{array}$ & 51.75 & 15.10 & & 18 & $\begin{array}{r}\text { Xidayang } \\
\text { reservoi }\end{array}$ & 50.15 & 35.01 \\
\hline & 4 & $\begin{array}{r}\text { Xidayang } \\
\text { reservoi }\end{array}$ & 26.49 & 7.38 & 2002 & 19 & $\begin{array}{r}\text { Xidayang } \\
\text { reservoi }\end{array}$ & 38.73 & 19.74 \\
\hline & 5 & $\begin{array}{c}\text { Angezhuang } \\
\text { reservoir }\end{array}$ & 19.10 & 5.77 & & 20 & $\begin{array}{r}\text { Wangkuai } \\
\text { reservoir }\end{array}$ & 59.14 & 31.04 \\
\hline \multirow{2}{*}{1984} & 6 & $\begin{array}{l}\text { Wangkuai } \\
\text { reservoir }\end{array}$ & 44.75 & 14.31 & 2003 & 21 & $\begin{array}{r}\text { Wangkuai } \\
\text { reservoir }\end{array}$ & 234.97 & 116.34 \\
\hline & 7 & $\begin{array}{r}\text { Xidayang } \\
\text { reservoi }\end{array}$ & 31.16 & 12.19 & 2004 & 22 & $\begin{array}{r}\text { Yuecheng } \\
\text { reservoir }\end{array}$ & 417.00 & 159.00 \\
\hline \multirow{3}{*}{1992} & 8 & $\begin{array}{l}\text { Wangkuai } \\
\text { reservoir }\end{array}$ & 45.14 & 27.09 & 2005 & 23 & $\begin{array}{c}\text { Angezhuang } \\
\text { reservoir }\end{array}$ & 83.50 & 42.51 \\
\hline & 9 & $\begin{array}{r}\text { Xidayang } \\
\text { reservoi }\end{array}$ & 30.10 & 16.21 & \multirow{3}{*}{2006} & 24 & $\begin{array}{c}\text { Angezhuang } \\
\text { reservoir }\end{array}$ & 32.00 & 8.28 \\
\hline & 10 & $\begin{array}{c}\text { Angezhuang } \\
\text { reservoir }\end{array}$ & 34.13 & 18.80 & & 25 & $\begin{array}{r}\text { Wangkuai } \\
\text { reservoir }\end{array}$ & 114.60 & 48.44 \\
\hline 1997 & 11 & $\begin{array}{c}\text { Angezhuang } \\
\text { reservoir }\end{array}$ & 79.97 & 51.98 & & 26 & Yellow river & 200.00 & 100.00 \\
\hline 1998 & 12 & $\begin{array}{c}\text { Angezhuang } \\
\text { reservoir }\end{array}$ & 33.06 & 21.50 & 2008 & 27 & Yellow river & 312.00 & 157.60 \\
\hline 1999 & 13 & $\begin{array}{c}\text { Angezhuang } \\
\text { reservoir }\end{array}$ & 27.43 & 17.80 & 2009 & 28 & $\begin{array}{c}\text { Angezhuang } \\
\text { reservoir }\end{array}$ & 70.00 & 20.00 \\
\hline \multirow{2}{*}{2000} & 14 & $\begin{array}{c}\text { Angezhuang } \\
\text { reservoir }\end{array}$ & 31.11 & 15.00 & - & - - & - & - & - - \\
\hline & 15 & $\begin{array}{r}\text { Wangkuai } \\
\text { reservoir }\end{array}$ & 75.00 & 40.60 & Total & - - & - & 2351.56 & 1090.36 \\
\hline
\end{tabular}

Baiyangdian watershed is one of the primary grain-produce areas in north China, and the ratio of agricultural water is high. For instance, in 2006, the total water used in Baiyangdian watershed was 3.217 billion $\mathrm{m}^{3}$, and agricultural water was 2.696 billion $\mathrm{m}^{3}$, which accounted for $83.8 \%$ of the total water used. The construction of controlled reservoir in upstream watershed also greatly promotes the development of irrigation and drainage engineering. So far, 35 irrigation districts above 667 hectares have been 
constructed, among which there are 4 large irrigation districts (Shahe, Tanghe, Yishui, Fanglaizhuo) above 2001 hectares and 31 medium irrigation districts (above 667 hectares and smaller than 2001 hectares). The whole effective irrigation area of cultivated land in watershed is 78706 hectares. The increasing of agricultural water in the upstream watershed would necessarily cause the runoff into Baiyangdian Lake decreased, especially in drought year, the conflict between agricultural water and water required in Baiyangdian Lake was more obvious. It would be aggravate rapidly the deterioration trend of water eco-environment in Baiyangdian Lake.

\subsubsection{Environmental Hydrology Situation Changed a Lot in Upstream Watersheds, and Wastewater Discharge Quantity in the Watersheds Increased Rapidly}

Except Baigouyin River of the 8 rivers whose water quality was good, water qualities of other rivers were worse than the water quality standard of Grade V. Fu River mainly undertook the domestic wastewater of Baoding City[17], Xiaoyi River mainly undertook the industrial wastewater from Li and Gaoyang counties, Cao River and Bao River mainly undertook the domestic and industrial wastewater from Mancheng and Xushui counties, respectively. Meanwhile, the increasing of agricultural land area in the upstream watersheds caused the application of chemical fertilizer and pesticide increased sharply, so the non-point pollution from agriculture was also one of the main pollution sources. The pollutants discharged from Fu River and Cao River were the most of the 8 rivers. Fu River flows through the center of Baoding City, Cao River flows through the northwestern part of Baoding City. In the past 40 years, the daily wastewater discharge in Baoding City increased continuously. The daily wastewater discharge of Baoding City in 1962 was $0.43 \times 10^{5}$ tons, which was $1.6 \times 10^{5}$ tons in 1974 and $2.1 \times 10^{5}$ tons in 1987. The daily wastewater discharge of Baoding City was $2.5 \times 10^{5}$ tons in 2005, and it was still increasing. However, at present there are only two wastewater treatment plants with a total daily treatment capacity of $1.6 \times 10^{5}$ tons, which results in $0.9 \times 10^{5}$ tons wastewater flowing into Fu River without being treated, and becomes the biggest pollution source in Baiyangdian Lake. Cao River was not polluted before the middle of 1980s. After the middle of 1980s, 156 paper mills were constructed in the upstream watershed of Cao River, and the daily wastewater increased to $0.8 \times 10^{5}$ tons, which was discharged into Cao River only after simple treatment except $0.3 \times 10^{5}$ tons wastewater was treated by Daceying Town wastewater treatment plant. In addition, with the domestic wastewater discharged from Mancheng County, Cao River had become a Sewage River. Fig. 13 showed the monitoring results of the five main pollutants concentration $\left(\mathrm{NH}_{4}{ }^{+}-\mathrm{N}, \mathrm{COD}_{\mathrm{Mn}}, \mathrm{BOD}_{5}, \mathrm{TP}, \mathrm{TN}\right)$ in the estuary of Fu River and Cao River to Baiyangdian Lake from 1988 to 2008. The result showed that all pollutants concentrations fluctuated greatly inter-annually and annually. The $\mathrm{NH}_{4}{ }^{+} \mathrm{N}, \mathrm{COD}_{\mathrm{Mn}}$ and $\mathrm{BOD}_{5}$ concentrations showed obvious decreasing tendency after the year 2002, however the TP and TN concentrations were more stable which showed a slight increasing tendency. 


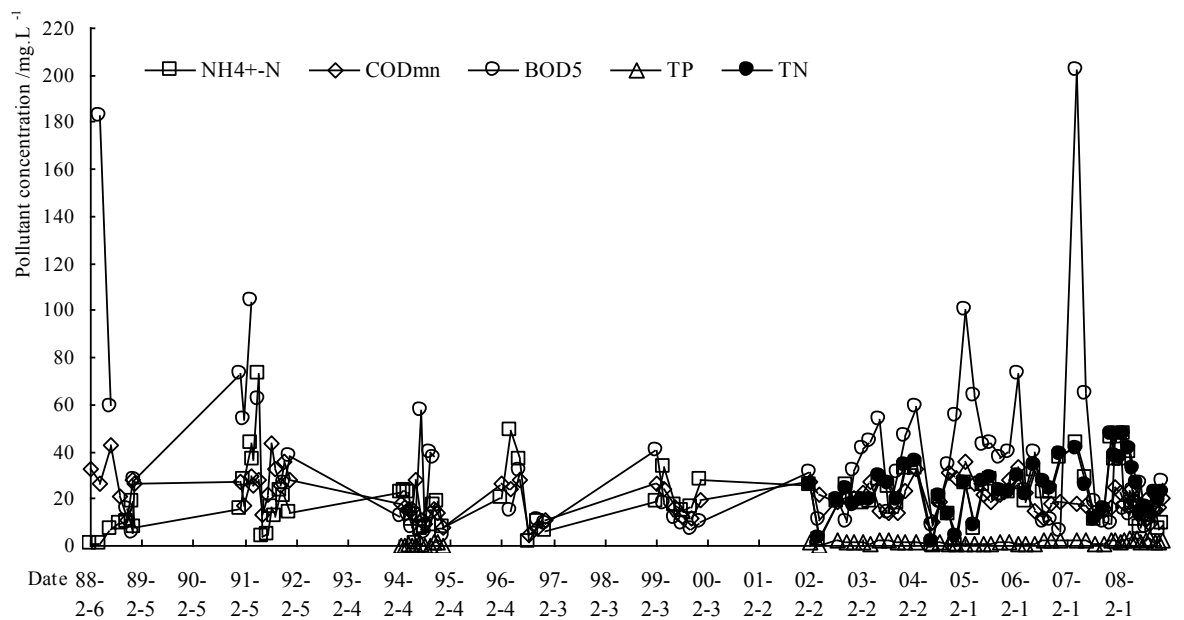

(a) Fu River

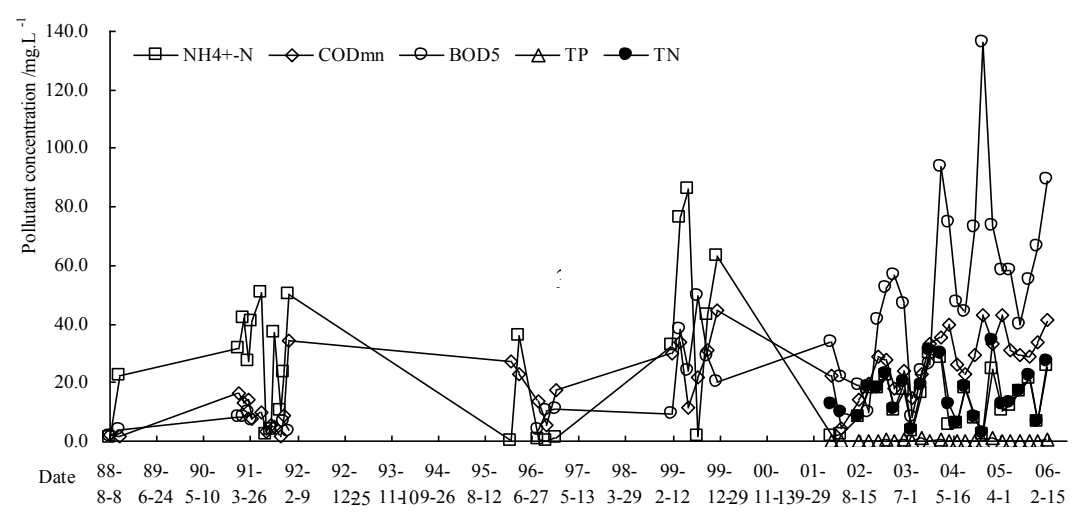

(b) Cao River

Fig. 13. The Dynamic Changes of the Concentrations of River Pollutants in Baiyangdian

From Fig.13 (a), it could be found that the water quality of Fu River was worse than the standard of Grade V, the five pollutants concentrations were far beyond the standards. The average concentrations of $\mathrm{NH}_{4}{ }^{+}-\mathrm{N}, \mathrm{COD}_{\mathrm{mn}}$ and $\mathrm{BOD}_{5}$ were $19.88 \mathrm{mg} / \mathrm{L}$, $20.83 \mathrm{mg} / \mathrm{L}$ and $34.29 \mathrm{mg} / \mathrm{L}$, respectively, which were 10 times, 1.4 times and 3.5 times the water quality standard of Grade $\mathrm{V}$. The annual average concentrations of TP and TN were $1.44 \mathrm{mg} / \mathrm{L}$ and $24.34 \mathrm{mg} / \mathrm{L}$, which were 7 times and 12 times more than the standard of Grade V. From Fig.13 (b), it could be found that Cao River mainly discharged oxygen consumed pollutants, and the $\mathrm{BOD}_{5}$ and $\mathrm{COD}_{\mathrm{Mn}}$ concentrations were high, which were 3.6 times and 2.2 times the standard of Grade V. The average concentration of $\mathrm{NH}_{4}{ }^{+}-\mathrm{N}$ was $21.14 \mathrm{mg} / \mathrm{L}$, which was 10 times the standard of Grade $\mathrm{V}$. 
The concentration of TP was $0.27 \mathrm{mg} / \mathrm{L}$, which was similar to the standard of Grade $\mathrm{V}$. The concentration of TN was 8 times the standard of Grade V.

\subsubsection{The Sharp Increasing of Human Activity Directly Caused the Water Requirement in Baiyangdian Lake Increase Greatly}

In the recent years, the population in Baiyangdian Lake increased greatly, which increased from 364,800 in 1989 to 387,800 by now, and the results of remote sensing interpretation also showed the residential land increased from $820.4 \mathrm{hm}^{2}$ in 1987 to $1490.0 \mathrm{hm}^{2}$ in 2007 . The increasing of population in Baiyangdian Lake directly caused the discharge of domestic wastewater increased.

After the water refilling with Baiyangdian Lake in 1988, the tourism developed quickly. As recorded, it received the tourists 3,704,000 from 1988 to 2000, and the peak of daily received tourists was 6833[18]. The water consumption and domestic pollutants of tourists, and the pollutants discharged by the motorboats accelerated the artificial pollution in Baiyangdian Lake.

From the 1950s, the counties and cities around Baiyangdian Lake continually developed agricultural irrigation. The agricultural water around lake increased from $2 \times 10^{7} \mathrm{~m}^{3}$ per year in the early $1950 \mathrm{~s}$ to $2 \times 10^{8} \mathrm{~m}^{3}$ now. The increasing of water diversion decreased the regulating storage volume of Baiyangdian Lake, which brought a series of environmental problems.

\section{$5 \quad$ Results}

Four categories of conclusions have been achieved based on the research in this paper:

(1) Monitoring with remote sensing on the water ecological landscape pattern in Baiyangdian Lake, it was found that the emergent plants, water body and cultivated land were the main land use types. During 1974 and 2007, the water body and emergent plants areas were decreased respectively by $28.7 \%$ and $20.8 \%$, while the cultivated land areas were increased by $69.7 \%$. And the heterogeneity and landscape fragmentation degree of different landscape types decreased constantly, but the latter wasn't to the significant difference level.

(2) During 1988 and 2008, the main pollutants $\left(\mathrm{NH}_{4}{ }^{+}-\mathrm{N}, \mathrm{COD}_{\mathrm{Mn}}, \mathrm{BOD}_{5}, \mathrm{TP}, \mathrm{TN}\right)$ concentrations changed greatly with obvious spatial-temporal characteristics by analyzing the water quality data, and the pollutants concentrations showed increasing tendency. The pollution of North Zone was most severe in the whole lake, and the pollution was more serious in summer of normal and dry years, while the pollution was serious at the beginning of summer flood in wet years, and then became less.

(3) The local climate changed obviously in Baiyangdian Lake with Mann-Kendall test, which the precipitation decreased, while the air temperature and evaporation increased. The warming and drying climate tendency intensified water eco-environmental degradation, and the precipitation was the main impact factor on the changes water eco-environment in lake.

(4) Sharp increasing of human activity directly caused ecological/environmental hydrology regime in upstream watershed of Baiyangdian Lake changed obviously, which made it changed from a natural controlled lake-wetland to a totally artificial regulated lake. 
Acknowledgements. We are grateful for financial support by the Program for New Century Excellent Talents in University (NETC-10-0708), National Basic Research Program of PR China (973 Project, 2009CB421100), the National Natural Science Foundation for Innovation Team of China (No. 40701189) and the Science Fund of China Postdoctor (No.20080430072).

\section{References}

1. Wang, H.: Study on creative ideas and key countermeasures of lake-wetland water ecological pollution treatment, pp. 22-25. Science Press, Beijing (2010)

2. Chinese Society of Environmental Sciences: The 13th World lake Conference, pp. 1-860. China Agricultural University Press, Beijing (2010)

3. Cui, B.S., Li, X., Zhang, K.J.: Classification of hydrological conditions to assess water allocation schemes for Lake Baiyangdian in North China. J. Hydrol. 385(1-4), 247-256 (2010)

4. Hu, G.C., Luo, X.J., Li, F.C., Dai, J.Y., Guo, J.Y., Chen, S.J., Hong, C., Mai, B.X., Xu, M.Q.: Organo chlorine compounds and polycyclic aromatic hydrocarbons in surface sediment from Baiyangdian Lake, North China: concentrations, sources profiles and potential risk. J. Environ. Sci. 22(2), 176-183 (2010)

5. Zhao, X., Cui, B.S., Yang, Z.F.: A study of the lowest ecological water level of Baiyangdian Lake. Acta Ecol. Sinica 25(5), 1033-1040 (2005)

6. Xu, M.Q., Zhu, J., Huang, Y., Gao, Y., Zhang, S., Tang, Y.: The ecological degradation and restoration of Baiyangdian Lake, China. J. Freshw Ecol. 13(4), 433-446 (1998)

7. Gao, Y.C., Wang, H., Long, D.: Changes in hydrological conditions and the eco-environmental problems in Baiyangdian watershed. Resour. Sci. 31(9), 1506-1513 (2009)

8. Li, Y.H., Cui, B.S., Yang, Z.F.: Influence of hydrological characteristic change of Baiyangdian on the eco-environment in wetland. J. Nat. Resour. 19(1), 62-68 (2004)

9. State Forestry Administration, P.R. China. Technical Specification for Investigating the National Wetland Resources (2009)

10. Vapink, V.N.: The nature of statistical learning theory, pp. 1-24. Springer, New York (2005)

11. Oded, M., Lior, R.: The data mining and knowledge discovery handbook, pp. 41-84. Springer Science and Business Media Inc. (2005)

12. Hofmann, H., Lorke, A., Peeters, F.: Temporal scales of water-level fluctuations in lakes and their ecological implications. Hydrobiologia 613, 85-96 (2008)

13. Chen, L.D., Fu, B.J.: Analysis of impact of human activity on landscape structure in Yellow River Delta - a case study of Dongying Region. Acta Ecol. Sinica 16(4), 337-344 (1996)

14. Li, C.Z., Yu, F.L., Liu, J.: Dynamic change of landscape and its driving forces in midstream of Heihe mainstream basin after water redistribution. Acta Ecol. Sinica 29(11), 5832-5842 (2009)

15. Zhong, P., Yang, Z.F., Cui, B.S., Liu, J.L.: Eco-environmental water demands for the Baiyangdian Wetland. Environ. Sci. Eng. China 2, 73-80 (2008)

16. Zhang, S.Z., Tian, J.W., Li, G.B.: Ecological problems and restoration measures of Baiyangdian Wetland. Bull. Soil and Water Conserv. 27(3), 146-150 (2007)

17. Hu, G.C., Dai, J.Y., Mai, B.X., Luo, X.J., Cao, H., Wang, J.S., Li, F.C., Xu, M.: Concentrations and accumulation features of organo chlorine pesticides in the Baiyangdian Lake freshwater food web of North China. Arch. Environ. Contam. Toxicol. 58(3), 700-710 (2009)

18. Zhang, M.Y.: Study on the change of eco-environment in Baiyangdian watershed based on RS, GIS and landscape pattern analysis, pp. 1-58. Nanjing Normal University, Nanjing (2004) 